\title{
As lógicas do recrutamento político
}

A observação empírica mostra que a probabilidade de exercer um poder político (seja qual for) aumenta conforme a posição na hierarquia social e que a posição social de origem (medida, por exemplo, pela última profissão antes da entrada na política) dos políticos é tanto mais elevada quanto mais altas as posições ocupadas na hierarquia política ${ }^{1}$.

Independentemente do cargo considerado (prefeito, gestor departamental, candidato às eleições legislativas, deputado ou ministro), pode-se estabelecer uma correlação estreita entre a representação política de um grupo e a posição social de seus membros². Dados coletados por mais de um século atestam, por exemplo, que o índice de representação política $^{3}$ na Câmara dos Deputados aumenta regularmente quando se vai

Artigo publicado originalmente na Revue Française de Science Politique, vol. XXX, n. 1, fevereiro de 1980, sob o titulo "Les logiques du recrutement politique". Direitos autorais Presses de Sciences Po e Revue Française de Science Politique. Tradução de Patrícia C. Ramos Reuillard. Revisão da tradução por Luis Felipe Miguel.

* Professor do Departamento de Ciência Política na Universidade de Paris I Panthéon-Sorbonne (Paris, França). É autor de La Démocratie représentative (2003).E-mail: Daniel.Gaxie@univ-paris1.fr

1 Analisei essas relações em um trabalho sobre os fatores sociais do sucesso político: Gaxie (1983, p. 441-465). O material empírico que sustenta essas conclusões não pode ser reproduzido aqui por falta de espaço.

2 Medida pelo volume global do capital (econômico, social e/ou cultural) de que dispõem os grupos de agentes.

3 Índice calculado desde modo:

$\frac{\% \text { de deputados originários de uma dada categoria social }}{\% \text { dessa categoria na população ativa }} \times 100$

- Revista Brasileira de Ciência Política, nº8. Brasília, maio - agosto de 2012, pp. 165-208. 
das classes populares às classes superiores e que todas as categorias que compõem as classes superiores (grandes produtores rurais, industriais e grandes empresários, profissionais liberais, altos executivos dos setores privado e público, professores e intelectuais diversos) estão frequentemente sobrerrepresentadas (índice superior a 100) e, na maioria, fortemente sobrerrepresentadas, ao passo que todas as frações das classes médias ou populares (com a significativa exceção dos professores primários) estão sub-representadas na Câmara, quando não estão ausentes ${ }^{4}$. Desse modo, a representação parlamentar fornece uma imagem invertida da estrutura social, visto que mais de três quartos dos deputados provêm do decil mais favorecido - social e culturalmente - da população. Desse ponto de vista, a competição política interessa (em todos os sentidos), acima de tudo, a todos os agentes situados no topo da hierarquia social, ou melhor, às diferentes frações das classes superiores. Correlatamente, as características sociais do corpo político tornam-se mais "aristocráticas" à medida que se galga a hierarquia de poder e de prestígio dos cargos em competição. Assim, a porcentagem dos agentes que pertencem às classes superiores aumenta quando se avança nas hierarquias partidárias ou quando se vai dos prefeitos e gestores departamentais aos candidatos a deputados, dos candidatos aos eleitos ou dos deputados aos ministros.

Basta, portanto, deixar o livre jogo da concorrência política agir para que agentes privilegiados pelas hierarquias sociais ${ }^{5}$ se apossem das posições de poder político e assim reforcem a supremacia social e a autoridade política que a marca. Nas condições de um mercado político simbolicamente hierarquizado, a concorrência política só pode ser uma forma de seleção social.

Confirmam-se essas afirmações a contrario pela constatação de que apenas a introdução de disposições restritivas e decisórias pode contrariar as leis gerais do recrutamento político enunciadas acima. Introduzindo regras implícitas ou explícitas - por exemplo, a cota mínima de represen-

\footnotetext{
Os números variam um pouco conforme as relações de força eleitorais ou os regimes políticos, mas a relação global subsiste, essencialmente, ao longo de todo o período.

Não somente as hierarquias entre os grupos sociais sob o aspecto do capital econômico ou cultural, mas também as hierarquias fundadas na origem étnica, na faixa etária ou no sexo.
} 
tação feminina, adotada pelo congresso de Nantes do Partido Socialista, ou a preferência do Partido Comunista pelos quadros de origem operária ou popular nas promoções internas -, as organizações políticas podem impedir parcialmente a lógica seletiva dominante da competição política. Aliás, no PCF, onde se vê a maior originalidade do corpo político, percebe-se mais claramente como as modalidades do sucesso político se encontram expressas conforme a lógica própria da competição interna dos partidos ou, na verdade, conforme as características sociais de suas lideranças. Ao mesmo tempo em que assumiam o poder interno, os dirigentes comunistas de origem operária promoveram a cânone da biografia militante as características sociais, principalmente a origem de classe, em nome das quais pretendiam dirigir o partido. E é ao preço de um controle social e de uma vigilância constante que os quadros encarregados da cooptação impõem, contra os mecanismos externos que penetram o partido e "trabalham" em sentido inverso, as normas de recrutamento, que são sua própria justificativa de existência enquanto dirigentes e, ao mesmo tempo, o fundamento mais legítimo de seu poder interno.

O caso particular do PCF permite, desse modo, determinar como um grupo hegemônico dentro de um partido e socialmente homogêneo pode "refratar" as modalidades da concorrência política, perpetuando o poder de seus membros e contribuindo para possibilitar relações duradouras de trocas com diversas categorias, classes ou frações de classes.

Correlatamente, as relações privilegiadas que se estabelecem entre os organismos políticos e certos grupos sociais tendem a especificar as condições gerais da concorrência e do sucesso políticos, favorecendo o recrutamento de quadros em consonância com a base social do partido e reforçando os laços entre o partido e sua base.

O estudo das condições sociais do sucesso político deve, portanto, ser aprofundado pela análise das modalidades através das quais as leis gerais do recrutamento político se encontram expressas e particularizadas conforme a lógica própria da concorrência interna a cada organização, uma maneira entre outras de estudar o problema clássico das relações entre os partidos e as classes ou frações de classes. 


\section{0 recrutamento social diferencial das lideranças partidárias ${ }^{6}$}

\section{Independentes, Republicanos independentes (RI) e Partido Republicano $(\mathbf{P R})^{7}$}

Liderado por agentes de origem especialmente elevada, o Partido Republicano fornece uma espécie de imagem arquetípica da seleção social do corpo político. As classes médias estão quase excluídas, e as classes populares se encontram totalmente relegadas de sua bancada parlamentar ao longo da história (Tabela 1). Se considerarmos que a maioria de seus "agricultores" eleitos são, na verdade, confortáveis proprietários de terras, mais de 98\% de seus quadros pertencem às classes superiores.

No entanto, o recrutamento não se efetua ao acaso nessas classes, mas privilegia algumas de suas frações. É o caso dos profissionais liberais que, já fortemente sobrerrepresentados no Congresso, o são ainda mais no PR. Dentro dessa tradição política, seu peso é máximo desde o início do século XX e seu declínio, embora sensível, manifestou-se mais tardiamente do que em outras situações.

A situação é idêntica no caso dos agricultores, cujos quadros constituem a segunda originalidade dos deputados republicanos. Pouco presente no

\footnotetext{
Na falta de dados mais gerais, a análise das características sociais das lideranças partidárias limitar-se-á aqui às dos parlamentares. Essa escolha forçada introduz um viés nas conclusões, pois, conforme os partidos, os deputados representam de modo desigual e imperfeito os dirigentes. Pode-se, entretanto, considerar que a posição social de origem dos deputados é uma aproximação bastante boa daquela das lideranças. Note-se, aliás, que as conclusões que tiraremos valem também para os dados relativos aos candidatos às eleições que, por falta de espaço, não puderam ser apresentados neste artigo.

Por convenção, a posição social de um agente é definida a partir da última profissão exercida. Os políticos só foram considerados como permanentes quando nunca exerceram outra atividade. A caracterização de um político a partir de uma profissão que exerceu em um passado distante e por um curto período é, sem dúvida, sociologicamente contestável quando se trata de apreciar sua posição social real e explicar suas práticas. Em contrapartida, ela me parece pertinente para analisar as condições sociais do recrutamento político. Portanto, a linha de raciocínio deste artigo será baseada principalmente na categoria social de origem dos quadros políticos - que será distinguida da origem social medida, por exemplo, pela profissão do pai -, sem levar em conta o grau de profissionalização desses quadros. No geral, retomei as nomenclaturas e as convenções do Instituto francês de estatísticas e análises econômicas (INSEE), salvo no caso dos jornalistas e dos permanentes dos partidos, que agrupei com as profissões intelectuais diversas.

Tentei raciocinar sobre um período histórico suficientemente longo para atenuar as discrepâncias estatísticas conjunturais e para considerar a evolução histórica. Assim, fui levado a fazer agrupamentos um tanto arbitrários (caso do PR, ligado aos Independentes, ou do CDS, ligado ao MRP por intermédio do CD). Por convenção, e para evitar enumerações cansativas, utilizarei a última legenda em caso de modificação.
} 
Congresso, essa categoria, composta principalmente de proprietários ou de grandes produtores, frequentemente de origem nobiliária, ocupa um importante lugar neste partido, ainda que em declínio.

Grande parte dos deputados republicanos também vem do segmento dos industriais e grandes comerciantes. Todavia, a originalidade do PR é menos clara aqui. O lugar dessa categoria nos quadros do PR é, de fato, pouco superior ao que ela ocupa na Câmara (ao passo que era nitidamente superior na Quarta República ${ }^{8 *}$ ), e outros partidos, como a RPR ou o CDS, caracterizam-se por uma maior proporção de deputados originários desses meios. Diferentemente de outras frações do polo econômico, os altos executivos do setor privado têm pouco peso entre os deputados republicanos, até menos do que na Câmara como um todo. Em contrapartida, a porcentagem dos deputados originários da alta função pública aumentou nitidamente desde 1958; entretanto, é pouco maior do que a média da Câmara, sendo até inferior à da RPR. Em compensação, a originalidade do PR é muito mais clara no que tange ao polo intelectual. As profissões intelectuais, sobretudo os professores, estão de fato bem menos representadas nessa organização em todos os períodos de sua história do que no Congresso e seu declínio é particularmente forte, já que os professores são quase sempre eliminados de seus quadros durante a Quinta República.

As lideranças do Partido Republicano provêm, portanto, de um setor muito limitado do espaço social coberto pelas classes superiores ${ }^{9}$ e se caracterizam por seu pertencimento às categorias tradicionais e não assalariadas do polo econômico (entre 50 e $70 \%$ de grandes produtores rurais, industriais e profissionais liberais, conforme as legislaturas). Embora as classes médias estejam muito pouco representadas no partido, seus raros agentes são originários ${ }^{10}$ do polo econômico dessa classe (artesãos e pequenos comerciantes). A esses membros tradicionais vieram recentemente se somar lideranças oriundas da alta função pública, frequentemente ligadas, por suas origens familiares, fortuna pessoal, alianças matrimoniais ou carreira, aos proprietários de terras e à burguesia econômica de velha cepa.

\footnotetext{
8 *A Terceira República é o regime político da França de 1870 a 1940; seguida da Quarta República (1946-1958) e da atual Quinta República, regida pela Constituição de 1958 (NT).

Sobre esse ponto, ver o esquema da página 191.

${ }^{10}$ Conforme o princípio de homologia formulado mais adiante.
} 


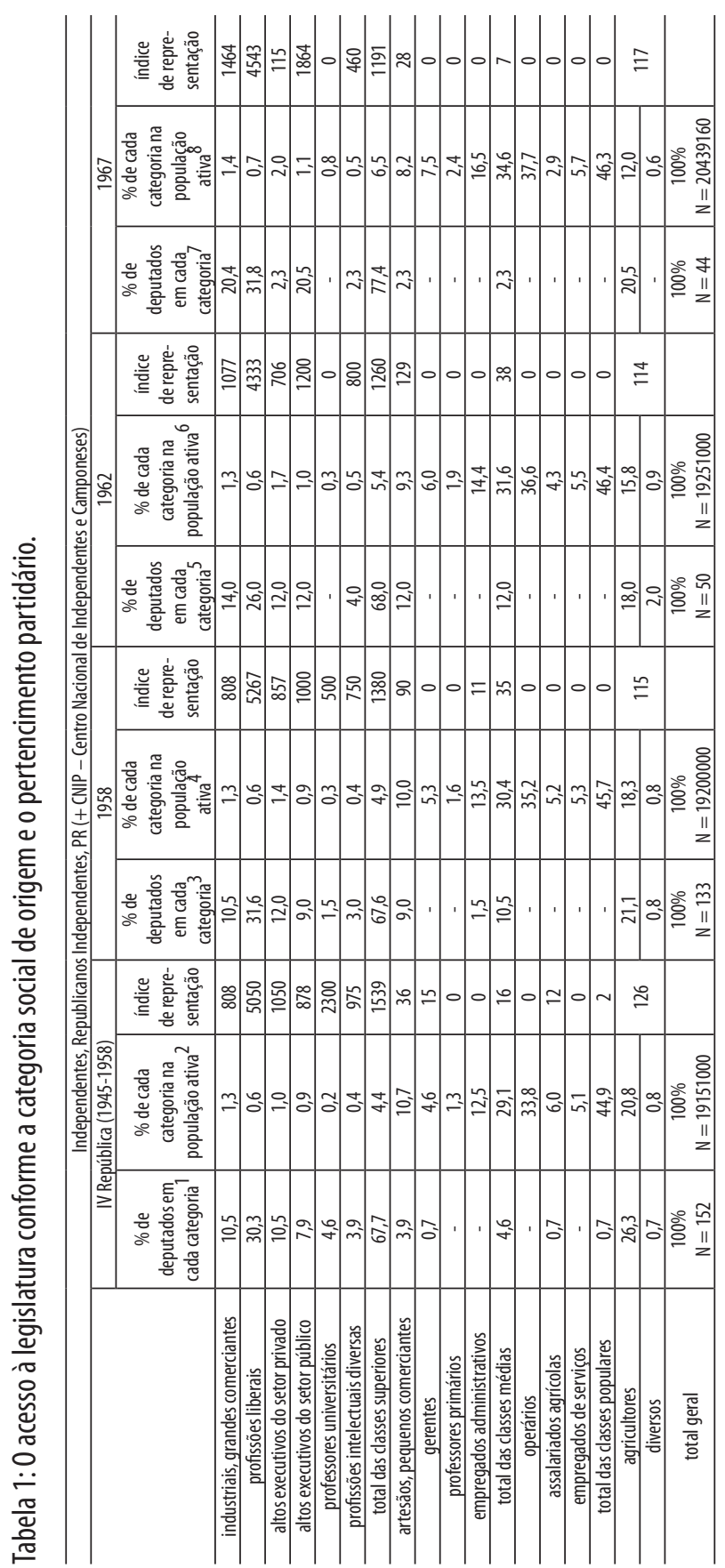




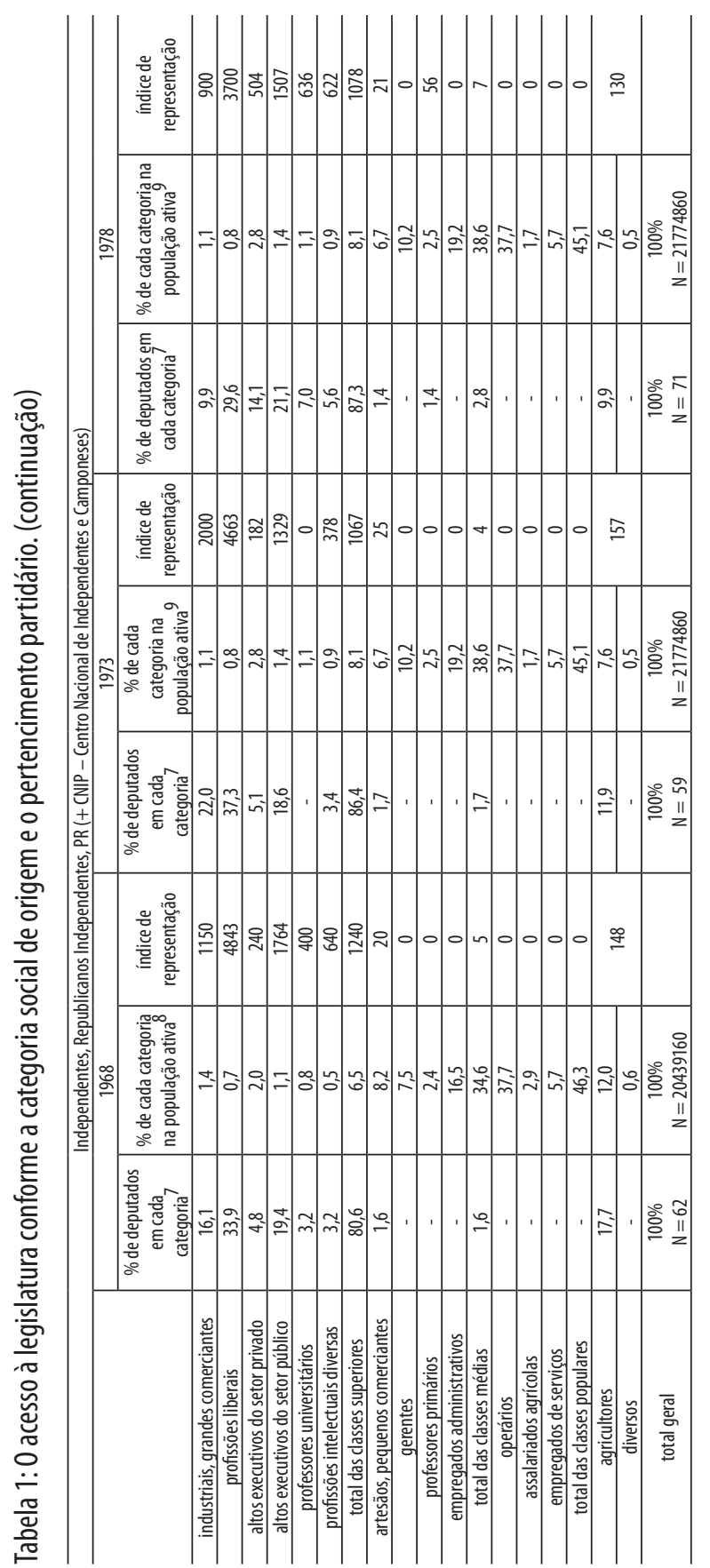

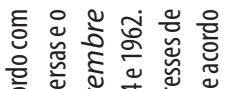

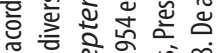

品

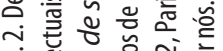

సิ

ㄴ.

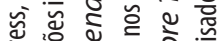

ัँ

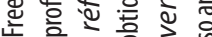

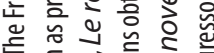

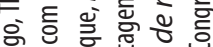

을 응 응 능 응

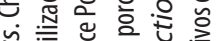

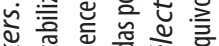

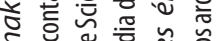

ह 융 :

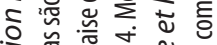

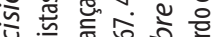

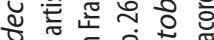

응 흔 는 ธัँ

옹 끙 은

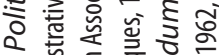

흘 छ․ㅡㄹ 흥

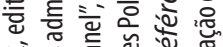

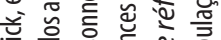

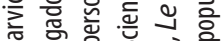

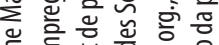

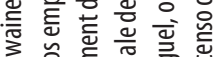

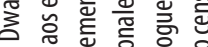

틍 을 흄 을

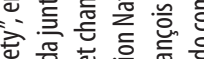

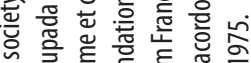

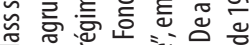

훙 흥 응

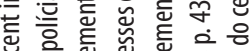

产产产范

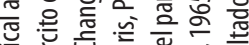

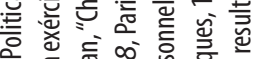

․ㅡㄴ 든

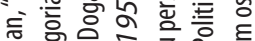

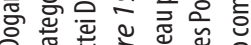

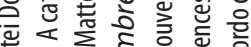

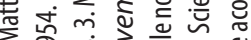

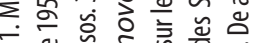

ํㅡㅇ

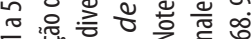

ธ 뜌.

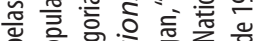

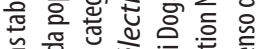

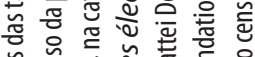

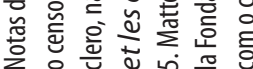




\section{União pela Nova República (UNR), União dos Democratas pela República (UDR) e Coalizão pela República (RPR)}

Embora o índice de representação na RPR, assim como no PR, aumente conforme a posição na hierarquia social, as lideranças deste partido ocupam posições mais baixas do que as republicanas. A bancada parlamentar da RPR, cujos membros pertencentes às classes superiores são de origem social mais baixa do que os republicanos ${ }^{11}$, caracteriza-se ainda por uma porcentagem maior de deputados das classes médias, estando ausentes da bancada (Tabela 2) suas frações mais desfavorecidas (empregados administrativos) e as classes populares, como no PR. Além de sua origem social mais baixa, as lideranças da RPR se distinguem pelo lugar ocupado pelos industriais e, sobretudo, pelos altos executivos dos setores público e privado, cujo peso é máximo. Os profissionais liberais também estão muito representados, mas sensivelmente menos do que no PR. A RPR se diferencia igualmente deste pela sub-representação dos agricultores e pela presença do polo intelectual. Os professores são menos numerosos na RPR do que no Congresso, e o declínio que enfrentam nesse partido é mais ou menos paralelo ao que sofreram nessa instituição, mas, contrariamente ao $\mathrm{PR}$, eles não estão totalmente ausentes da bancada parlamentar.

A distribuição das lideranças que pertencem às classes médias é homóloga à constatada nas classes superiores. O polo econômico está representado em proporções análogas às do $\mathrm{PR}$, mas, como no caso das classes superiores, a RPR recruta igualmente entre as frações assalariadas (gerentes), e até mesmo no polo intelectual (professores primários), porém mais raramente.

Pelo lugar ocupado pelos profissionais liberais, industriais e grandes comerciantes nos cargos diretivos, a RPR mostra-se portanto ligada, assim como o PR (excetuando os agricultores), à burguesia econômica não assalariada, especialmente às frações mais baixas, menos tradicionais, com menos capital cultural ou de ascensão mais recente. Ela ocupa, em segundo lugar, uma superfície mais ampla do espaço social das classes superiores ${ }^{12}$, já que um número significativo de suas lideranças é oriundo dos dirigentes assalariados dos setores público e privado e mesmo de certos

\footnotetext{
11 O pai de 84\% dos deputados RI eleitos em 1968 e pertencentes às classes superiores pertencia a essas mesmas classes contra 67\% dos eleitos da UDR (Cayrol, Parodi e Ysmal, 1973, p. 52-53).

${ }^{12}$ Cf. esquema da página 190.
} 
meios intelectuais. A originalidade da RPR em relação aos outros partidos vem, então, mais do lugar privilegiado que reserva aos altos executivos da administração ou das empresas privadas do que da presença da burguesia econômica e liberal.

Assim como no PR (e, conforme veremos, no CDS), os dirigentes da RPR estão principalmente ligados, por suas origens, ao polo econômico das classes superiores (secundariamente, também ao das classes médias) e aos setores da alta função pública ligados ao polo econômico; porém, a RPR se diferencia de seus aliados "puxando" seu recrutamento mais para as frações centrais, até mesmo intelectuais ${ }^{13}$, das classes superiores (e médias) ${ }^{14}$.

Na medida em que essas nuanças no recrutamento expressam oposições sociais, poderíamos dizer que as relações entre a RPR e o PR são o espelhamento, na ordem política, das relações entre a nova burguesia econômica (com mais frequência) assalariada e a burguesia econômica tradicional.

14 Note-se que os efeitos produzidos pela homologia de estruturação das classes médias e superiores se manifestam plenamente aqui. Sobre esse ponto, cf. infra. 


\begin{tabular}{|c|c|c|c|c|c|c|c|c|c|c|c|c|c|c|c|c|c|c|c|}
\hline 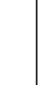 & \begin{tabular}{ll}
\multirow{2}{*}{} \\
\hdashline
\end{tabular} & $\stackrel{m}{=}$ & 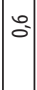 & $\approx$ & $\stackrel{-}{\therefore}$ & $\underline{n}$ & 능 & 落 & $\Omega^{2}$ & : & $\approx$ & 志 & $\frac{0}{m}$ & కొ: & s & 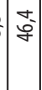 & $\left|\begin{array}{l}\infty \\
\vdots \\
2 \\
2\end{array}\right|$ & & 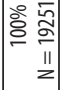 \\
\hline 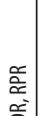 & 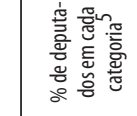 & $\stackrel{\Xi}{E}$ & 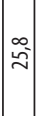 & 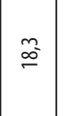 & 号 & in & $\stackrel{\ddagger}{*}$ & $\bar{\Omega}$ & $\stackrel{0}{0}$ & $\bar{m}$ & ' & $\bar{m}$ & $\stackrel{\infty}{\beth}$ & छे & & a & in & & 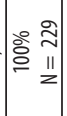 \\
\hline 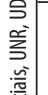 & 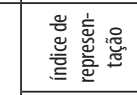 & ڤ̊ & 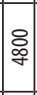 & 突 & 守 & $\stackrel{\tilde{\vartheta}}{\sim}$ & 守 & $\stackrel{\overline{0}}{\circ}$ & q & : & $\bar{m}$ & $\stackrel{n}{\sim}$ & $\approx$ & 010 & 0 & 0 & & & \\
\hline 产 & 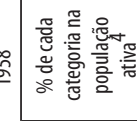 & $\stackrel{m}{=}$ & 응 & $\stackrel{\Xi}{\leftrightarrows}$ & gे & $\tilde{\sigma}$ & 혀 & $\stackrel{q}{\forall}$ & $\stackrel{\circ}{\circ}$ & nn & $\stackrel{0}{-}$ & $\stackrel{\tilde{m}}{m}$ & 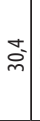 & $\begin{array}{lll}2 & = \\
m & 2\end{array}$ & $\begin{array}{lll}c & m \\
n & n & \end{array}$ & $\sqrt{8}$ & 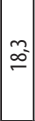 & - & 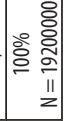 \\
\hline 䋉 & 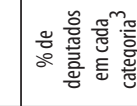 & $\bar{m}$ & $\left|\begin{array}{l}\infty \\
\stackrel{\infty}{\infty}\end{array}\right|$ & 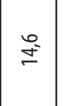 & $\stackrel{0}{\beth}$ & 욤 & 우 & $\bar{\infty}$ & $\stackrel{\circ}{f}$ & $\stackrel{m_{0}^{2}}{m}$ & $\tilde{2}$ & 오 & 응 & ' & ' & . & $\stackrel{0}{\circ}$ & & $\left(\begin{array}{c}\infty \\
0 \\
0\end{array}\right.$ \\
\hline & 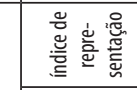 & $\approx$ & 总 & $\stackrel{\circ}{=}$ & So & 品 & 号 & 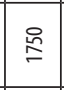 & $\widetilde{\sigma}$ & \pm & 0 & 0 & $\stackrel{\sim}{\sim}$ & $m$ & 0 & $\sim$ & & t & \\
\hline & 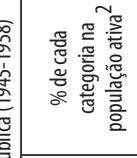 & $\stackrel{m}{-}$ & : & $\stackrel{-}{-}$ & 응 & $\tilde{\sigma}$ & $\stackrel{\Xi}{\circ}$ & $\stackrel{\forall}{*}$ & $\widehat{\circ}$ & \&: & $\stackrel{m}{=}$ & $\stackrel{\simeq}{\simeq}$ & $\overline{\mathbf{N}}$ & $\stackrel{\infty}{m}$ & : & $\begin{array}{l}q \\
f\end{array}$ & $\stackrel{\infty}{2}$ & $\stackrel{\infty}{\circ}$ & 응 $\frac{8}{\frac{0}{2}}$ \\
\hline & 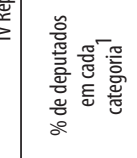 & $\stackrel{\infty}{\sigma}$ & $\tilde{\nexists}^{-}$ & $\stackrel{\varrho}{=}$ & $\tilde{\tilde{m}}$ & $\approx$ & $\widetilde{\sim}$ & $\stackrel{2}{\Sigma}$ & $\stackrel{0}{0}$ & $=$ & ' & ' & 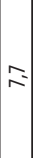 & $=$ & . & $\equiv$ & $\stackrel{\sim}{\tilde{m}}$ & $=$ & $\left(\begin{array}{cc}0 \\
8 & 11\end{array}\right.$ \\
\hline & & 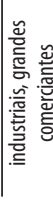 & 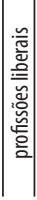 & 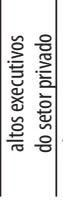 & 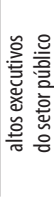 & 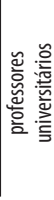 & 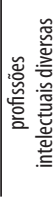 & 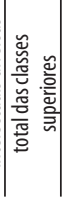 & 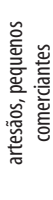 & 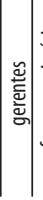 & 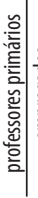 & 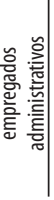 & 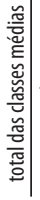 & | & 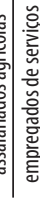 & 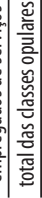 & & 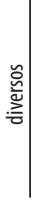 & 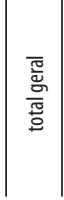 \\
\hline
\end{tabular}

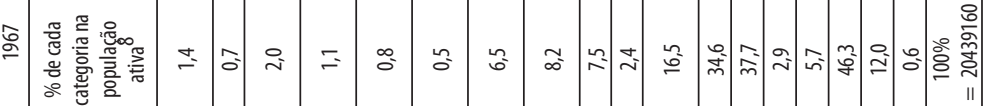

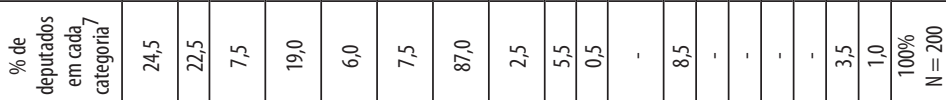

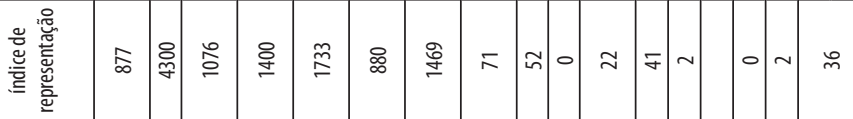

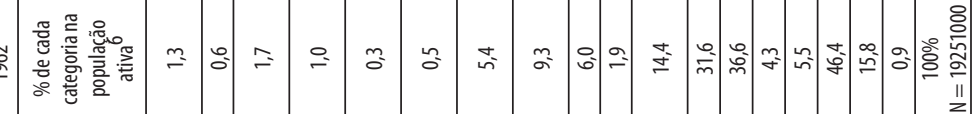
榇㝕 


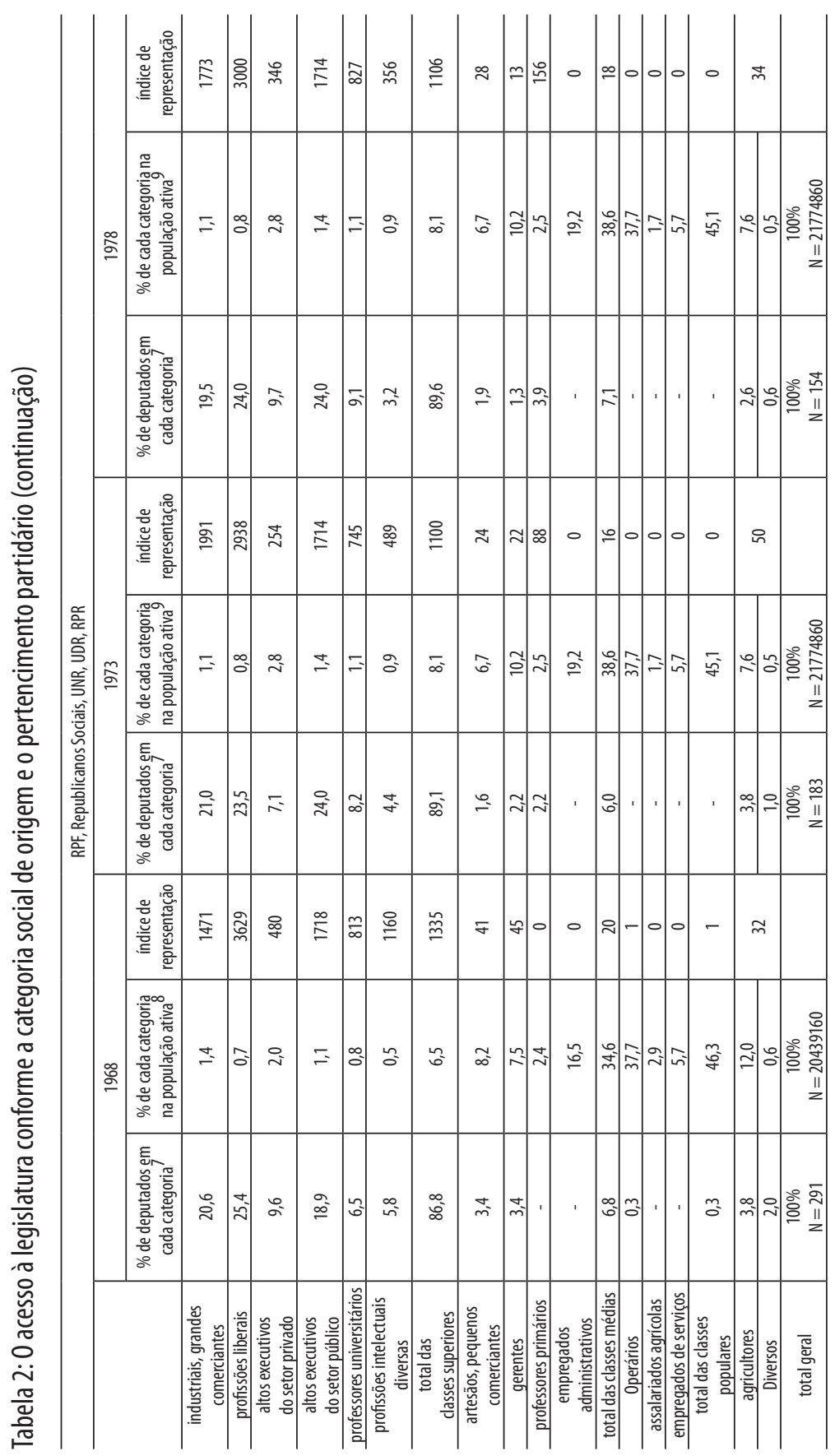




\section{Movimento Republicano Popular (MRP), Centro Democrata (CD), Progresso e Democracia Moderna (PDM) e Centro dos Democratas Sociais (CDS)}

Embora existam vínculos organizacionais entre as mudanças sucessivas da democracia cristã, os dados relativos a suas lideranças levam a duvidar da existência de uma verdadeira tradição política. De fato, é grande a distância entre a composição social dos círculos dirigentes do MRP e do atual CDS. O MRP se caracterizava pela sub-representação habitual das classes médias e pela exclusão das classes populares, além do lugar, superior à média da Câmara, das classes médias (Tabela 3). As características do CDS são, ao contrário, muito próximas do $\mathrm{PR}$, já que as classes populares estão ausentes e as classes médias se encontram pouco presentes (índice de representação inferior a 10). O MRP apresentava uma configuração original que incluía os altos funcionários dos setores público e privado (altos executivos e professores do ensino privado), categorias nitidamente mais representadas no MRP do que na Câmara até o início da Quinta República. Os industriais, os profissionais liberais e os produtores rurais eram, ao contrário, proporcionalmente menos numerosos nesse partido na Quarta República. Como com as classes superiores, eram as frações assalariadas das classes médias (executivos do setor público e empregados administrativos) que lideravam esse partido. Na Quinta República, o lugar dos altos executivos do setor privado e do polo intelectual diminuiu progressivamente em detrimento dos profissionais liberais, dos agricultores e dos industriais e, nos últimos anos da década de 1970, dos altos funcionários. O CDS tornou-se o partido em que o peso dos industriais é máximo, especificidade considerável da mesma forma que o lugar ocupado pelos agricultores, que se revela frequentemente muito próximo daquele que lhes reserva o $\mathrm{PR}$, às vezes superior.

A posição dos líderes dos partidos herdeiros da democracia-cristã se deslocou, portanto, na estrutura das classes superiores. À medida que se aliava aos Independentes e depois aos Radicais, o movimento "democrata-cristão" passou das frações intermediárias assalariadas das classes superiores ao polo econômico tradicional. Esse deslocamento estrutural (e, correlatamente, a transformação de sua base social?) provocou uma mudança das características sociais do partido. Os líderes 
apresentam agora os traços de um agrupamento muito comparável ao do PR (declínio acentuado do polo intelectual, presença da burguesia econômica não assalariada e da alta função pública). Do mesmo modo, a exemplo do que foi observado no $\mathrm{PR}$, a representação das classes médias só é garantida (salvo presença fugaz de alguns professores primários) por seu polo econômico (pequenos comerciantes). Como se as transformações sociais ocorridas na cúpula do CDS e as afinidades com o pessoal político do PR resultantes disso fizessem parte do movimento de alianças esboçado em $1974^{15^{*}}$.

15 * Quando os democratas cristãos, em declínio, se aliaram aos centristas, radicais e liberais na UDF, partido fundado por iniciativa do ex-presidente Valéry Giscrad d'Estaing (NT). 


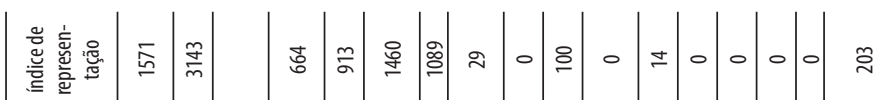

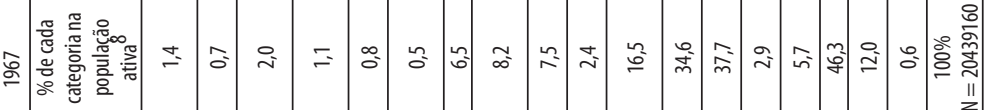

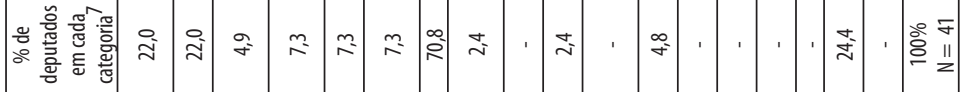

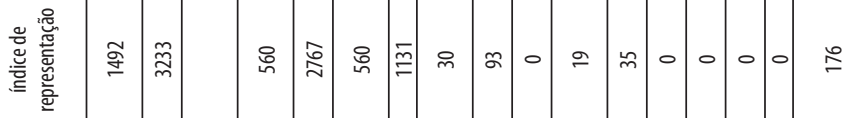

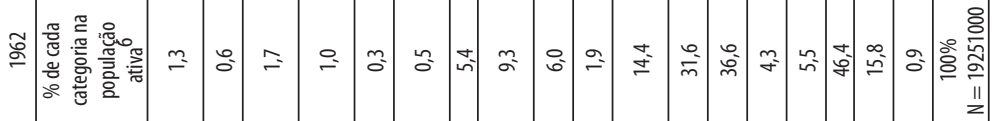

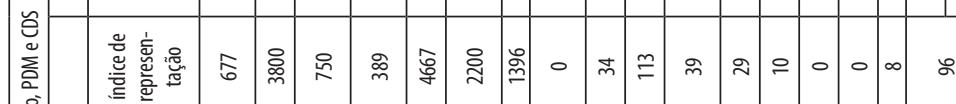

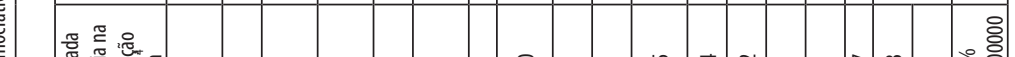

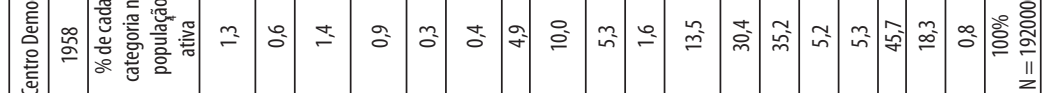
蕞

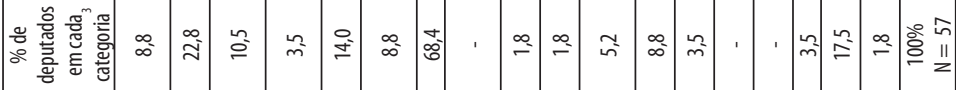

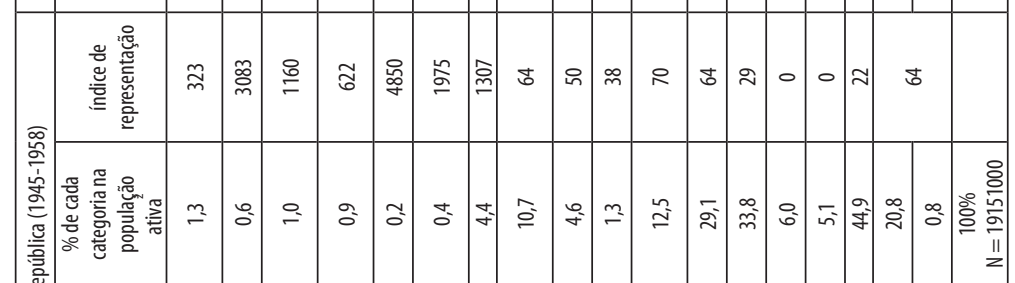
政

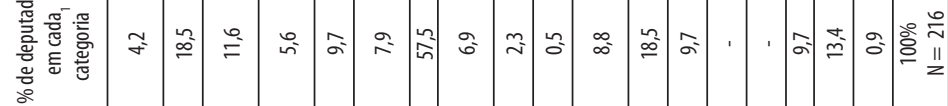

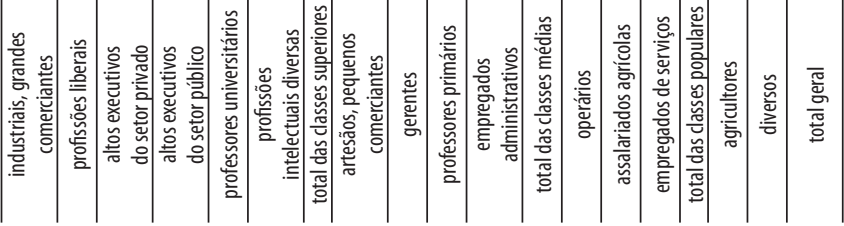




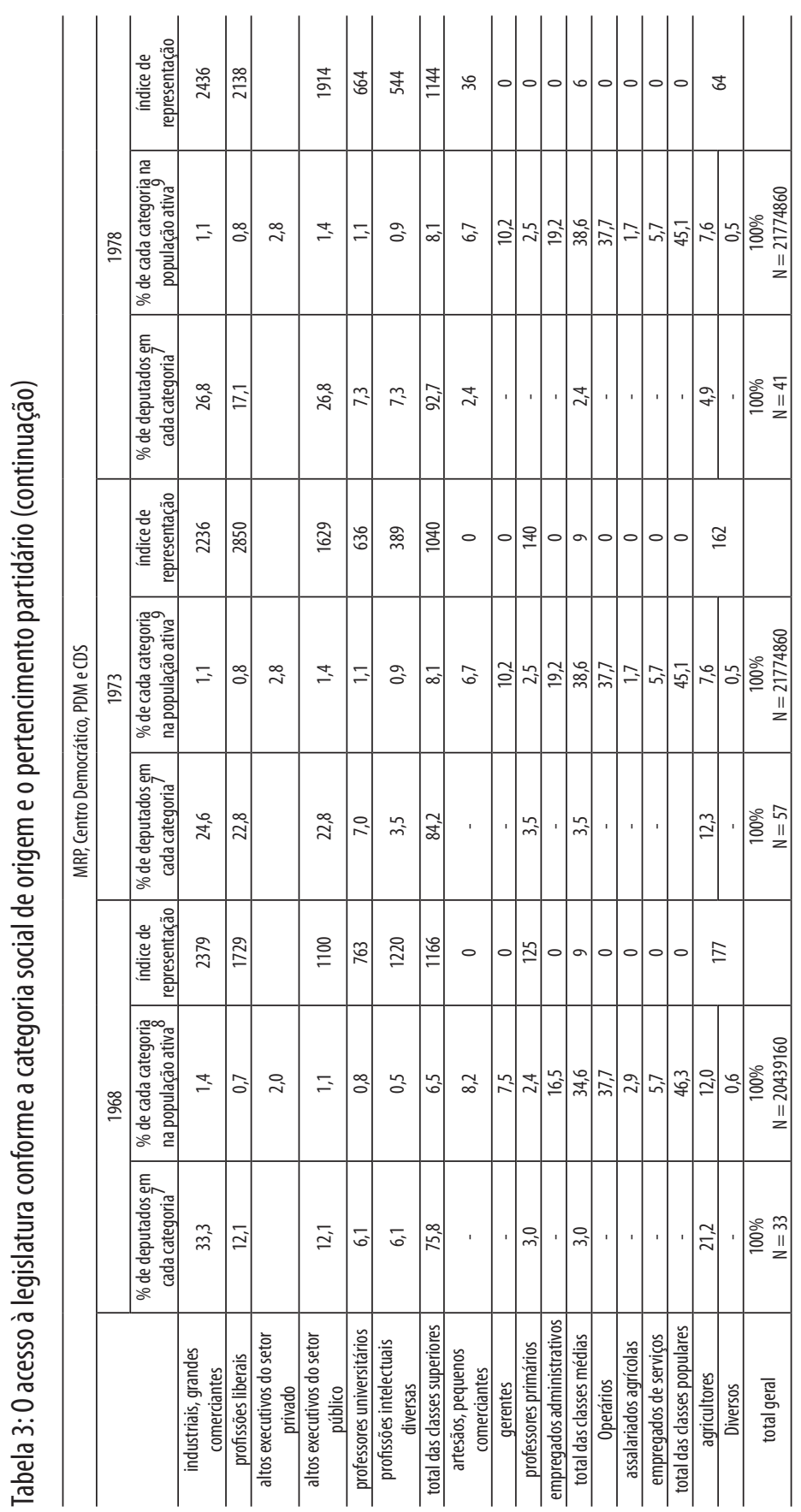




\section{Seção Francesa da Internacional Socialista (SFIO) e Partido Socialista (PS)}

A SFIO já havia perdido amplamente, na Quarta República, o caráter operário que ainda mantinha ao final da Terceira ${ }^{16}$, e essa tendência só se reforçou com a criação do Partido Socialista (Tabela 4). Embora não estejam completamente ausentes, os deputados originários das classes populares ocupam agora um lugar muito marginal no partido. A maior originalidade do Partido Socialista é, em compensação, a presença de lideranças provenientes das classes médias: ainda que estejam sub-representadas em relação ao peso de suas classes de origem na população ativa e que seus quadros estejam em declínio ${ }^{17}$, sua presença é constante e está longe de ser pequena.

Portanto, reencontramos no PS a tendência geral à exclusão dos agentes social e culturalmente desfavorecidos do exercício das atividades políticas e também o modo como a lógica de funcionamento de uma organização permite limitar esses efeitos, já que as classes médias, pouquíssimo presentes no PR, na RPR e no CDS, fornecem cerca de um quarto dos membros da bancada parlamentar socialista.

Essa reexpressão das leis gerais da seleção do pessoal político de acordo com a lógica da concorrência interna do partido (e a configuração da base social) se manifesta ainda pelo recrutamento bastante variável nas frações das classes médias. Os empregados administrativos foram progressivamente excluídos à medida que se elevava a origem das lideranças do PS e que se fortalecia o efeito de seleção social da competição interna, e os pequenos comerciantes estão tradicionalmente sub-representados nos círculos diretivos do partido, assim como, aliás, em seu eleitorado (cf. infra). O PS tende, ao contrário, a favorecer as novas classes médias do setor privado (executivos, serviços médicos e sociais) que, embora proporcionalmente

${ }^{16}$ 15\% dos deputados socialistas eleitos entre 1898 e 1940 são ex-operários (contra cerca de 35\% de operários na população ativa do período).

17 Pelo efeito acumulado da inércia do recrutamento parlamentar e da diferença de origem entre os quadros dirigentes da SFIO e do Partido Socialista, a posição social dos parlamentares socialistas é, em média, mais baixa do que aquela dos dirigentes do partido. Tudo leva a pensar (principalmente a evolução da composição da bancada parlamentar desde 1958, traçada na Tabela 4) que essa defasagem vai progressivamente ser reabsorvida. Os números apresentados aqui a partir dos efetivos parlamentares oferecem uma imagem um pouco mais "popular" dos quadros dirigentes do PS do que ela é na realidade. 
sub-representadas, não sofrem o desgaste das demais frações, sobretudo os professores, apesar do declínio acentuado de sua presença na liderança do PS, perceptível desde o fim da Terceira República.

Veem-se relações homólogas entre as diversas frações da classes superiores, que se encontram, no PS e nos outros partidos, amplamente sobrerrepresentados ${ }^{18}$, mas de modo desigual. Em suma, pode-se dizer que a sobrerrepresentação relativa no PS aumenta quando se vai do polo econômico ao intelectual. Desde 1958, o peso dos grandes comerciantes e dos industriais é maior na bancada parlamentar socialista do que na população ativa, mas em uma proporção sensivelmente menor do que a média da Câmara ou, a fortiori, do que o PR, a RPR ou o CDS. De resto, a criação do novo Partido Socialista acentuou essa tendência, já que, pela primeira vez desde a Quarta República, essa categoria apresenta, em 1978, um índice de representação inferior a 100 (Tabela 4). Em contrapartida, o peso relativo dos altos executivos do setor privado quase não tem variado ao longo dos últimos anos ${ }^{19}$ e permanece quase na mesma ordem de grandeza das demais bancadas parlamentares, à exceção do PCF; contudo, os dirigentes socialistas originários dessa categoria apresentam, como veremos, características atípicas.

O polo econômico das classes superiores se mostra, portanto, desfavorecido pela concorrência interna no Partido Socialista, como confirma, aliás, a ausência de progressão do peso relativo dos industriais ou dos altos executivos do setor privado quando se elevam o poder ou o prestígio dos postos em competição no $\mathrm{PS}^{20}$. Do mesmo modo, embora os profissionais liberais e os altos executivos do setor público estejam sobrerrepresentados no PS, quanto mais alta a hierarquia, seu índice de representação é mais baixo do que o do $\mathrm{PR}$, do CDS ou da $\mathrm{RPR}^{21}$ e se revela até inferior à média da Câmara para os profissionais liberais.

\footnotetext{
18 À exceção dos grandes produtores rurais, de um lado, e de certos setores do polo intelectual, como os artistas, do outro.

${ }^{19}$ A variação entre os dados de 1958 e 1962 (extraídos de Mattei Dogan) e os meus se explica provavelmente por diferenças nas convenções de codificação.

20 Por falta de espaço, não podemos reproduzir os elementos empíricos que sustentam essa afirmação.

${ }^{21}$ Note-se também que o índice de representação dos altos executivos do setor público está em regressão no OS, ao passo que aumenta ou fica mais ou menos estável nos outros partidos. Do mesmo modo, o declínio dos profissionais liberais é muito mais acentuado na bancada socialista do que nas demais bancadas.
} 
Em compensação, a originalidade do PS é mais marcada pelo recrutamento dos professores, cuja representação relativa aumentou muito desde a criação do novo Partido Socialista e permanece, de longe, máxima na bancada parlamentar socialista no decorrer da Quarta e Quinta Repúblicas.

Como outros partidos, o PS passou, portanto, por um deslizamento estrutural ou por vários deslizamentos em sua história. Distancia-se do polo intelectual na Quarta República e início da Quinta, período no qual o peso dos industriais, dos profissionais liberais, dos executivos do setor privado e dos altos funcionários tende a aumentar, ao passo que o dos professores diminui. Reaproxima-se do polo intelectual e se distancia correlatamente do polo econômico nos anos 1970. Mais uma vez, por trás da aparência da perenidade ou da continuidade organizacional, deveríamos falar de vários partidos que assumiram sucessivamente as mesmas etiquetas políticas. 


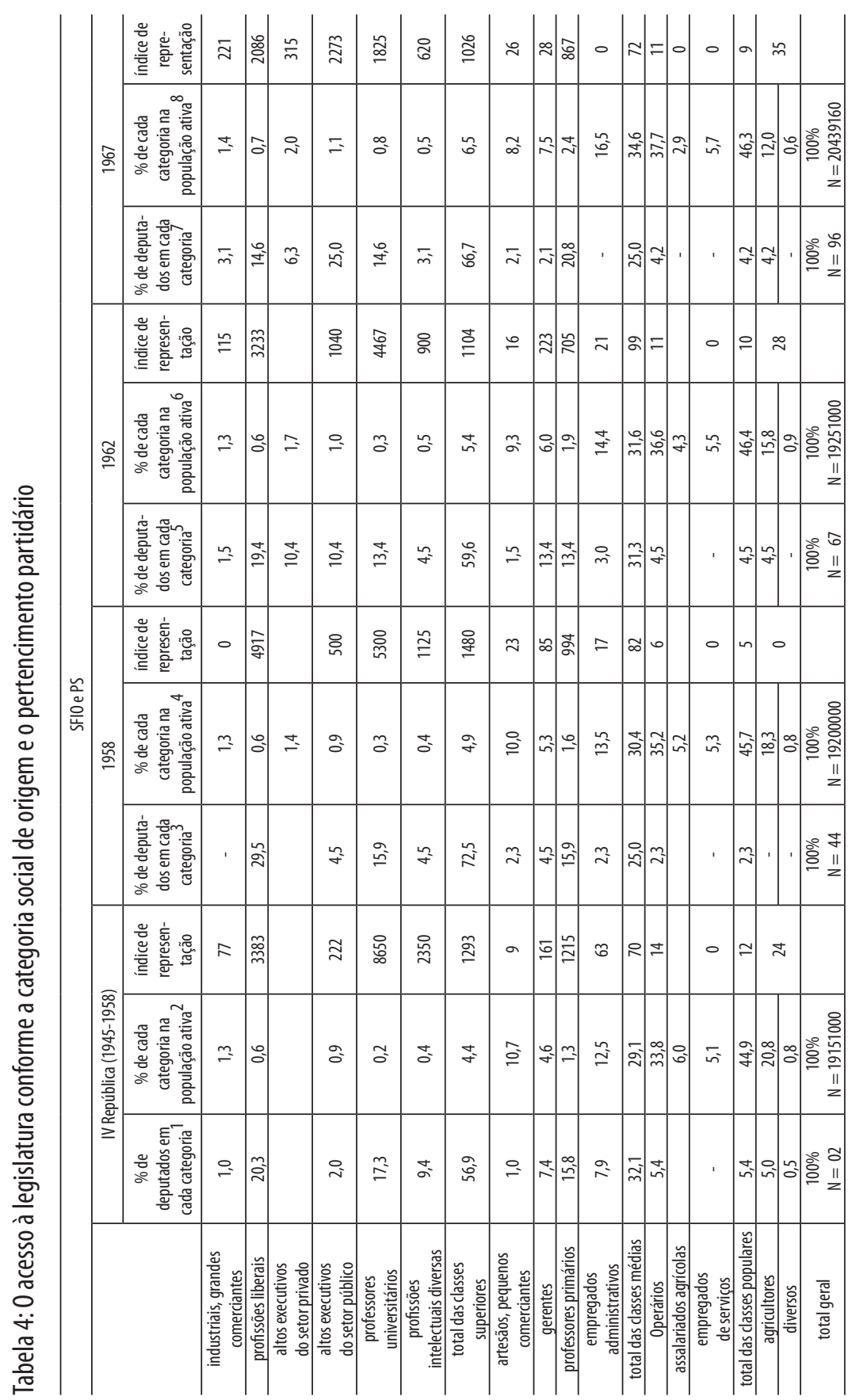




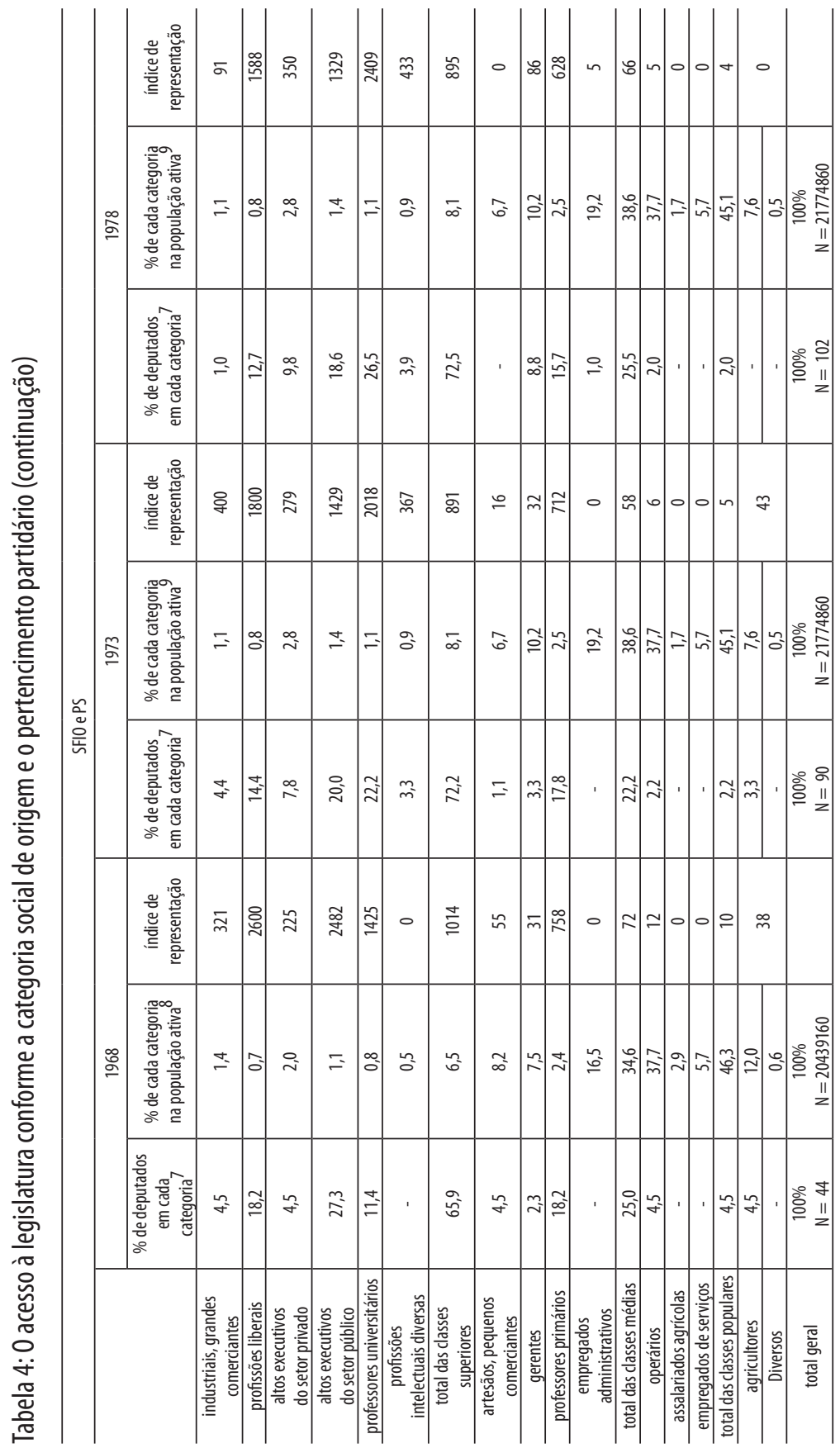




\section{Partido Comunista Francês (PCF)}

Embora a lei geral que estabelece que os grupos sociais estão ainda mais representados no Congresso quando ocupam uma posição mais alta na hierarquia social funcione no PCF (Tabela 5), os líderes deste partido apresentam uma originalidade na relação com os outros partidos. De fato, apesar de seu índice de representação aumentar quando se vai das classes populares às classes superiores ao longo de toda sua história, o PCF é o único partido no Congresso em que as classes populares se beneficiam de tão ampla representação, em que as classes médias são constantemente mais numerosas do que no eleitorado e onde as classes superiores são tão pouco sobrerrepresentadas (Tabela 5).

Com efeito, talvez contrariamente à imagem dominante do PCF, o peso das classes superiores é maior no partido do que na população ativa. Esse fenômeno, que tende a se acentuar, é verificado em todos os níveis da hierarquia interna, mas se revela muito particular nos mandatos eletivos submetidos aos julgamentos sociais externos ao partido. A porcentagem dos agentes que pertencem às classes superiores é, de fato, máxima entre os parlamentares, sobretudo entre os candidatos às eleições legislativas ou às recentes eleições europeias de 1979, que acentuaram uma evolução perceptível desde 1958. Todavia, o papel das classes superiores no partido rapidamente encontra limites. Em primeiro lugar, é nitidamente mais fraco do que aquele constatado nos outros partidos. Não varia de modo significativo conforme a posição na hierarquia interna e é até mesmo mais limitado nos postos decisivos da estrutura do poder interno, como os secretariados federais, o comitê central ou o gabinete político, do que nas posições mais secundárias na escala dos valores próprios ao PCF, como as candidaturas às eleições ou os mandatos eletivos ${ }^{22}$. Por fim, tange apenas a setores limitados das classes superiores. Ainda que a origem dos parlamentares comunistas originários dos meios favorecidos pareça se diversificar à medida que seus quadros avançam, o polo intelectual e, secundariamente, os profissionais liberais $^{23}$ são as únicas frações regularmente representadas ${ }^{24}$.

22 Portanto, no PCF as características da bancada parlamentar podem ser consideradas como o indicador mais aproximado daquelas das lideranças.

${ }^{23}$ Mais uma vez, a situação da bancada parlamentar é um tanto particular, pois os profissionais liberais não exercem, na hierarquia interna do partido, um papel comparável ao dos intelectuais. Só estes escapam, ocupando posições dominadas na estrutura interna do poder, à seleção social invertida praticada pelo PCF.

24 Salvo em 1958 e 1968. Ao que parece, os efetivos dos deputados originários das classes superiores regridem quando a conjuntura eleitoral é menos favorável ao PCF. Como se as normas de recrutamento que Ihe são próprias atuassem mais quando ele se volta para seus feudos eleitorais proletários. 
As demais frações só aparecem de vez em quando (altos executivos do setor privado) ou estão ausentes (industriais, altos funcionários). Por conseguinte, o PCF recruta em um setor ainda mais limitado do espaço social das classes superiores do que o PS. Somente os intelectuais, que apresentam traços específicos, conforme veremos, têm alguma chance de participar de sua direção.

O recrutamento nas classes médias é homólogo a essa representação das classes superiores. O polo econômico, praticamente ausente, só aparece de vez em quando por intermédio dos artesãos (situados mais abaixo na hierarquia das profissões independentes e mais próximas dos operários em razão das condições de vida); mais uma vez, é o polo intelectual que se encontra favorecido, por meio dos professores primários. Menor do que na SFIO na Terceira e Quarta Repúblicas, o peso dessa categoria se tornou comparável e até ligeiramente superior ao observado no PS. Como nesse partido, mas menos nitidamente, seus quadros parecem estar em declínio. Como se o aumento global da origem social dos deputados comunistas levasse os professores universitários a superar os professores primários. É surpreendente a homologia entre as características dos deputados comunistas, cujas posições sociais de origem são, de longe, as mais baixas de todos os deputados, e a representação diferencial das classes médias na bancada. São, de fato, as frações mais baixas dos executivos (principalmente os técnicos) que vêm se somar às frações mais baixas das classes médias (empregados administrativos) ou da hierarquia dos meios intelectuais (professores primários) e parecem aliás substituí-los.

Entretanto, a característica principal do PCF, de resto bem conhecida, é que os agentes sociais que pertencem às classes populares estejam fortemente representados no partido. Numerosos sinais revelam entretanto que, mesmo em um partido que se pretende representativo da classe operária, a tendência à exclusão política dos agentes mais desfavorecidos não desaparece totalmente. A lógica social que prejudica os agentes social e culturalmente desfavorecidos na competição política é de tal modo pregnante que seus efeitos se fazem sentir até no PS, no entanto organizado para derrubá-la. Os operários de fábrica (em geral, mais operários qualificados do que não qualificados ou trabalhadores manuais) e mais ainda as classes populares como um todo estão sempre sub-representados entre os candidatos às eleições legislativas e os deputados (Tabela 4) ou, de modo mais significativo, nos comitês federais.

Embora não escape totalmente ao efeito de seleção social induzido pela competição política, o PCF consegue ainda assim freá-lo. A vontade de pri- 
vilegiar os militantes de origem popular que caracteriza o recrutamento das lideranças é claramente percebida na composição social do grupo parlamentar.

Tanto os empregados quanto os operários estão proporcionalmente menos representados na bancada do que outras categoriais, mas seus quadros são (eram?) tradicionalmente comparáveis a seu peso na população ativa, ao passo que as condições da concorrência política, em outros partidos, levam à sua eliminação. $\mathrm{O}$ peso das classes populares tende, de resto, a aumentar conforme a posição na hierarquia partidária, sobretudo quando postos decisivos estão em jogo (caso dos secretários federais), e se manifesta mais nitidamente nos espaços reais de poder, como o comitê central ou o gabinete político, do que na bancada parlamentar.

Pelo desejo político de privilegiar a origem social em detrimento eventual da competência - linguística, oratória, estilística, cultural ou corporal - socialmente dominante, o PCF criou um mercado político específico. Nele, as qualidades socialmente reconhecidas encerram um traço negativo e, ao contrário, os traços de comportamento, que em outras situações constituem obstáculos à ascensão política ${ }^{25}$, são neutralizados ou, na maioria das vezes, se encontram consciente ou inconscientemente valorizados, acabando por se impor a todos que tentam se implantar nesse mercado, independentemente da violência que alguns possam então sofrer. Os mecanismos internos que concorrem para esse recrutamento na "contracorrente" se atenuam, por exemplo, quando a escolha dos candidatos às eleições deve compor com a imagem social do político ou quando o PCF se esforça para apagar as "asperezas" que freiam sua progressão e o processo de seleção social, recalcado mas sempre presente, faz novamente sentir seus efeitos. O aumento e a diversificação recentes da representação das classes superiores na bancada comunista e a regressão correlata da presença dos operários e dos empregados (os índices de representação de 1978 são os mais baixos da história do PCF: 83 para os operários e 60 para os empregados) talvez correspondam a um fenômeno dessa natureza. Note-se, no entanto, que as "defesas" habituais continuam a agir já que são principalmente as classes médias (empregados administrativos, professores primários), menos protegidas pela lógica seletiva própria ao PCF, que parece sofrer os contragolpes das transformações, aliás ainda tênues, das lideranças do PCF.

25 Por exemplo, a linguagem ou o sotaque. 


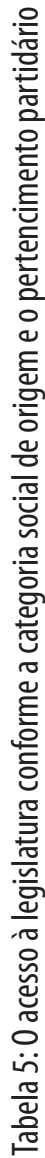

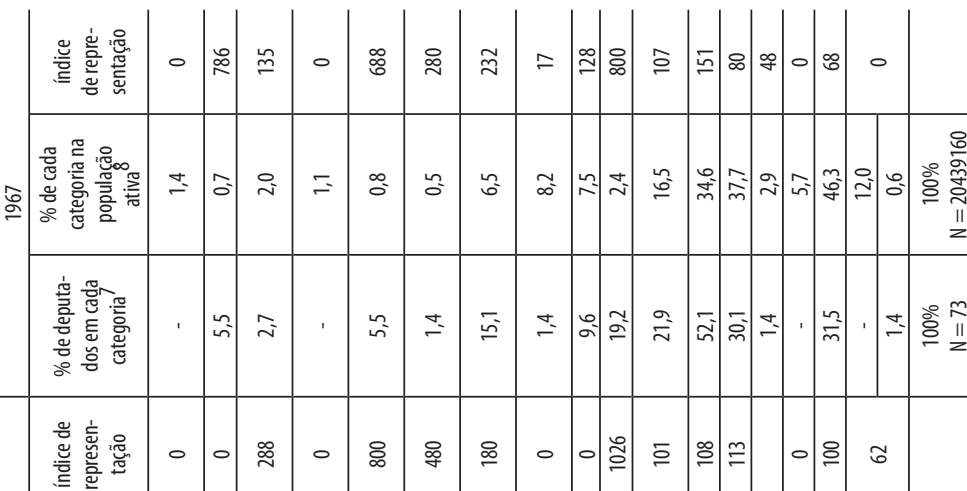

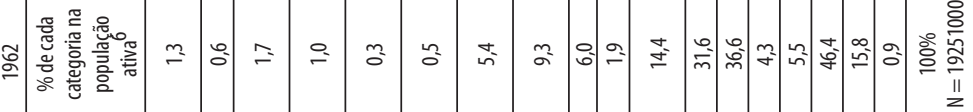




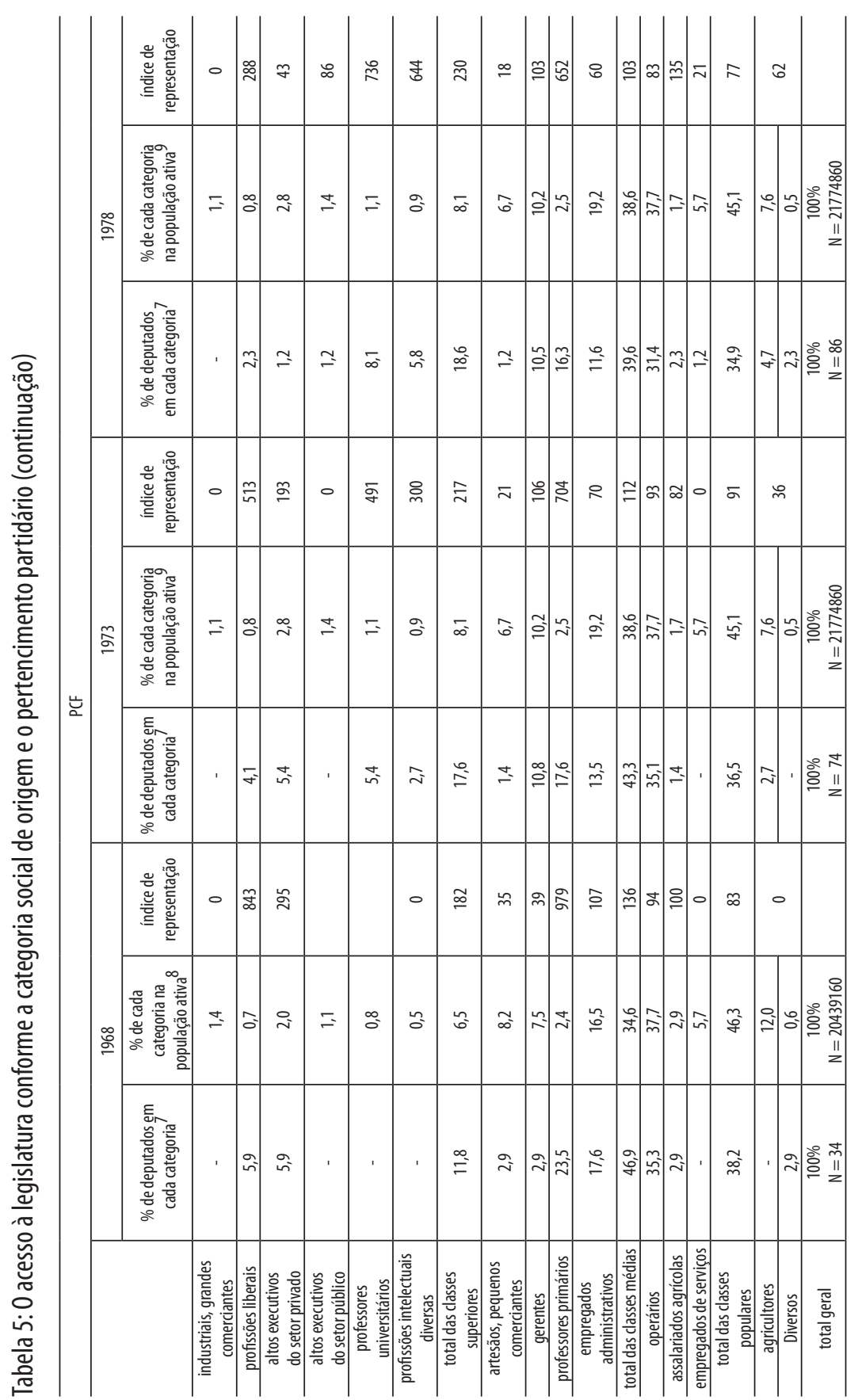




\section{Estrutura do campo político e estrutura social}

O aumento regular do índice de representação política conforme a posição na hierarquia social atesta que o efeito de seleção social inerente à competição política se manifesta, ainda que desigualmente, em todos os partidos. Essa seleção se exerce, entretanto, de maneira muito específica, ou seja, ao que parece, de acordo com os laços que cada organização mantém com a estrutura social.

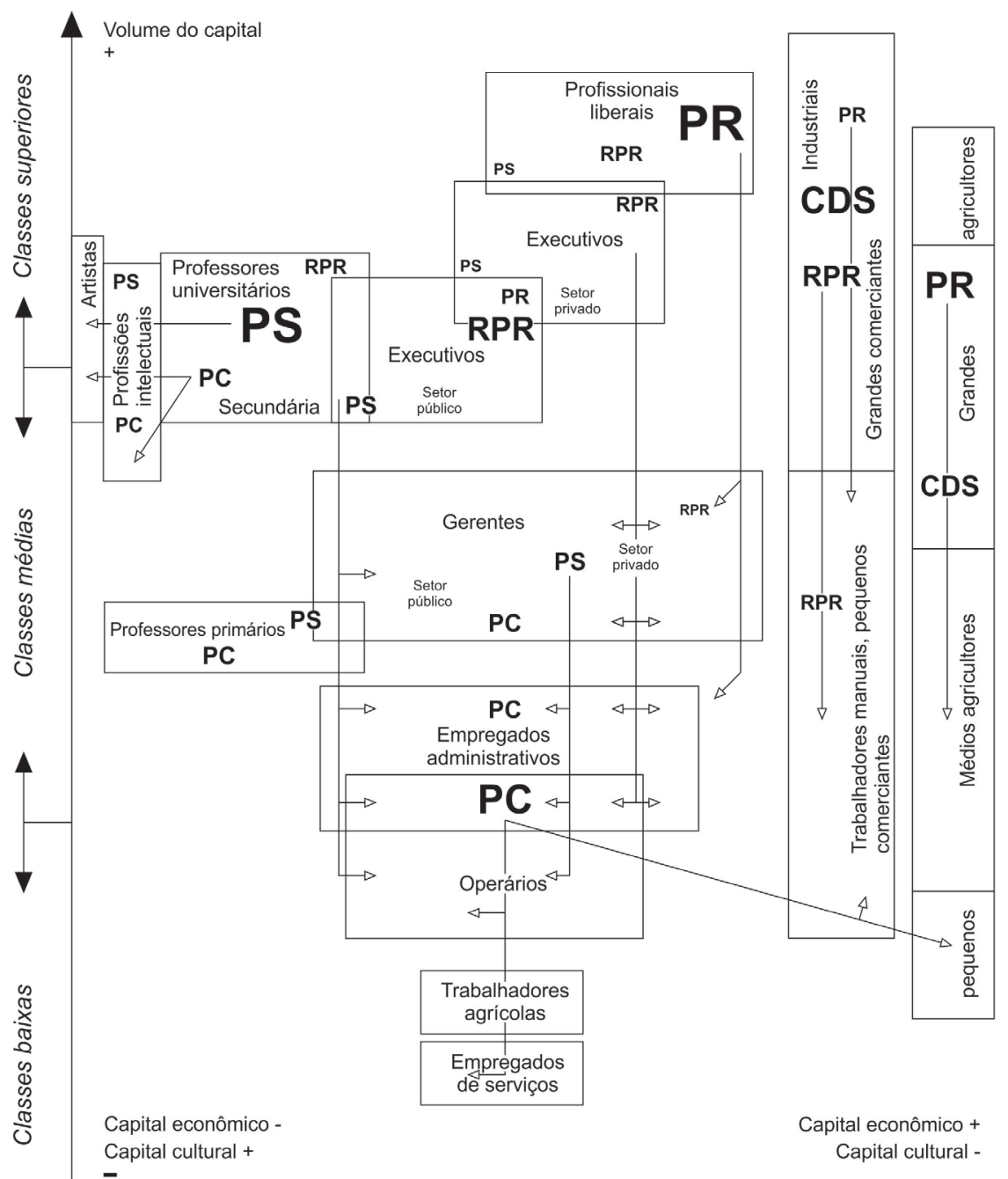

Estrutura do capital 


\section{Partidos, classes e frações de classe}

As lideranças de todos os partidos - com exceção do PCF - pertencem às classes superiores, mas vêm de frações nitidamente diferenciadas. O "espectro" das posições dentro do campo político se apresenta, aliás, como um decalque quase perfeito da estrutura das classes superiores ${ }^{26}$.

A cada fração relativamente bem definida das classes superiores corresponde uma organização política na qual a ascensão de políticos originários da fração parece favorecida. É possível, desse modo, detectar correspondências entre a burguesia econômica tradicional e a coalizão UDF (PR e CDS), entre a nova burguesia assalariada do setor público e privado e a RPR, entre uma fração da função pública superior e o PS, entre o campo intelectual e o PS ou o PCF (cf. esquema 1). Evidentemente, essa correspondência não deve ser analisada como uma relação unívoca entre frações ou subfrações das classes superiores e dos partidos políticos. O recrutamento do PR e do CDS privilegia os grandes produtores rurais, os profissionais liberais, os industriais e os grandes comerciantes, ou seja, uma parte relativamente significativa do espaço social coberto pela burguesia econômica. Os altos executivos do setor público ocupam, na $\mathrm{RPR}$, um lugar mais importante do que nas outras organizações, mas os executivos do setor privado estão na mesma situação. Já o PS recruta boa parte de suas lideranças na função pública superior, sobretudo entre os professores.

À exceção do PCF, no qual os intelectuais são praticamente os únicos membros das classes superiores com representação significativa, nenhum partido está ligado de modo exclusivo a uma fração específica. Inversamente, nenhuma fração vê sua representação limitada a um único partido. Não há partido dos intelectuais, como tampouco dos profissionais liberais ou da

\footnotetext{
${ }^{26}$ Pareceu-me interessante verificar se a estrutura das classes superiores e, mais precisamente, as lutas simbólicas entre frações de classes, descritas por Bourdieu e Saint-Martin (1976, p. 4-81) exerciam um efeito sobre o processo de recrutamento político. Para esses autores, o espaço social é submetido a dois princípios de estruturação: de um lado, o volume do capital possuído pelos agentes e, de outro, a estrutura desse capital, principalmente a parte relativa do capital econômico (rendas, patrimônio) e do capital cultural (diplomas, usos culturais). Se o pertencimento de classe está ligado ao volume do capital, o pertencimento à fração de classe depende da estrutura desse capital. Assim, nas classes médias e superiores, Pierre Bourdieu distingue um polo intelectual dominado, caracterizado pela predominância relativa do capital cultural em relação ao capital econômico, e um polo econômico dominante, em que o capital econômico sobrepuja o capital cultural. Por fim, certas categorias ocupam uma posição mediana na estrutura das classes assim constituída, umas "puxando" para o polo intelectual, outras para o polo econômico. Pode-se resumir essa concepção do espaço das posições sociais pelo esquema 1, que segue. É conhecido o lugar que Bourdieu atribui a essa luta das frações da classe dominante para a explicação dos comportamentos sociais nas áreas mais diversas. Era então interessante testar a sua pertinência para explicar o funcionamento do campo político.
} 
burguesia econômica ${ }^{27}$. Embora a correspondência entre partidos políticos e frações de classes não deva ser entendida de modo muito estrito, existem laços muito claros entre os grandes polos que estruturam as classes superiores e as organizações políticas. Resultados da Quinta, Quarta ou mesmo Terceira Repúblicas indicam que o polo econômico é tanto mais representado quando se vai, conforme as taxionomias em vigor no campo político, da "esquerda" para a "direita" ou para o "centro": em 1978, o índice de representação dos industriais e grandes comerciantes é de 0 no PCF, 91 no PS, 900 no PR, 1773 na RPR e 2436 no CDS; o índice dos profissionais liberais é respectivamente de 288 no PCF, 1588 no PS, 2138 no CDS, 3000 na RPR e 3700 no PR; enfim, para os altos executivos do setor privado, os números são respectivamente de 43 (PCF), 350 (OS), 346 (CDS), 350 (RPR) e 504 (PR $)^{28}$.

Nesse polo econômico, parece ser possível distinguir uma fração tradicional, proprietária dos meios de produção, cuja representação é via de regra máxima nas formações da atual UDF, e uma nova burguesia econômica assalariada, cujo peso é igualmente importante na $\mathrm{UDF}^{29}$, mas ainda maior na $\mathrm{RPR}^{30}$.

A porcentagem dos deputados originários dos meios intelectuais diminui, ao contrário, quando se vai da "esquerda" para a "direita" ou para o "centro" (em 1978, o índice de representação dos professores passa de 736 no PCF para 2409 no PS e depois diminui novamente para 827 na RPR, 664 no CDS e 636 no $\mathrm{PR}^{31}$ ).

Já a relação entre o lugar ocupado pelos altos executivos do setor público no espaço das posições sociais e a estrutura do campo político é menos clara e mais complexa. Exercendo no estado atual das relações sociais uma espécie de hegemonia no campo político, os altos funcionários estão presentes em quase todos os partidos. Muito pequeno no PCF, seu peso aumenta, entretanto, quando se vai do PS à RPR e decresce ligeiramente no CDS e no PR. Essa categoria parece ocupar no espaço político uma

${ }^{27}$ Observe-se que certas subfrações, principalmente as mais ligadas ao campo intelectual (artistas, pesquisadores) estão praticamente ausentes da competição política. O polo intelectual só intervém por meio de sua fração"institucional", que"se volta"em muitos aspectos para os executivos do setor público.

${ }^{28}$ Os dados obtidos para 1978 apresentam algumas diferenças de detalhes com os dados dos anos anteriores e infirmam parcialmente as relações enunciadas acima, extraídas do conjunto das séries estatísticas.

${ }^{29}$ E mesmo do PCF, mas, nesse caso, os executivos apresentam características atípicas que analisaremos mais adiante.

30 Essa relação é menos clara do que as outras e tem inúmeras exceções, por exemplo, em 1978.

31 Essa relação é igualmente verificada no interior dos partidos. Os professores eram, por exemplo, mais numerosos na "esquerda gaullista" do que na UDR como um todo. 
posição intermediária comparável àquela ocupada no espaço social pelas classes superiores. Seu peso se reduz quando um partido se "volta" para o polo intelectual (PS, sobretudo PCF) ou, menos nitidamente, para o polo econômico tradicional (PR e CDS).

Todavia, essas relações não devem ser interpretadas em termos mecânicos. Afirmar, por exemplo, que os partidos agrupados na UDF mantêm relações privilegiadas com as frações antigas e tradicionais da burguesia econômica não equivale a dizer que todos os deputados da UDF pertencem a essas frações. Salvo exceções (PCF e algumas vezes PR), todas as frações das classes superiores têm representação em todos os partidos. No máximo, constata-se que essa representação é desigual nos partidos e que a ascensão política de agentes originários de frações determinadas é mais fácil em algumas organizações do que em outras, mesmo que as diferenças às vezes sejam tênues ${ }^{32}$.

As relações entre as formações políticas e as frações de classes superiores devem ser interpretadas em termos de tendências, atestadas pelo grau de favorecimento da ascensão política de agentes originários de categorias sociais determinadas neste ou naquele partido. Em outras palavras, a existência de correspondências estáveis entre as estruturas de recrutamento social próprias a cada partido e a estrutura das classes superiores leva à hipótese de relações privilegiadas (o que não quer dizer exclusivas) entre os partidos políticos e as frações de classe, a menos que se considere que as diferenças constatadas entre os partidos não são estatisticamente pertinentes ou que não produzem efeitos externos.

As correlações estatísticas aqui comentadas tampouco devem induzir a uma visão simplista do funcionamento do campo político como puro reflexo das oposições de classes ou de frações de classe. Embora seja verdade que os grandes produtores rurais são proporcionalmente mais numerosos na UDF do que em outros partidos, não se pode deduzir que os agricultores estão, mesmo tendencialmente, representados na UDF por agricultores que defendem seus interesses. A análise da posição social diferencial das lideranças dos partidos permite apenas evidenciar as relações existentes entre as oposições políticas e as oposições sociais e pensar as primeiras como a expressão simbólica das segundas.

32 Assim acontece com diferenças que separam o RPR dos partidos da UDF. 
Esquema 2: Representação média relativa dos segmentos da classe alta por partido Índice de representação

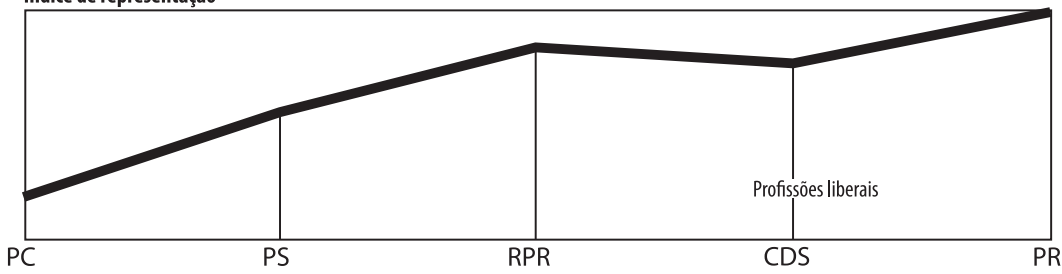

Índice de representação

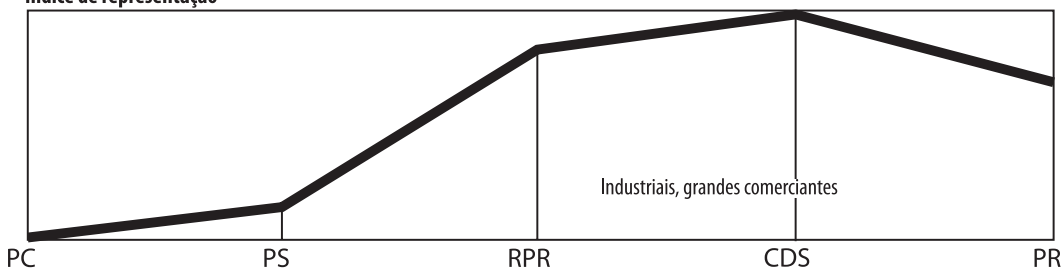

Índice de representação

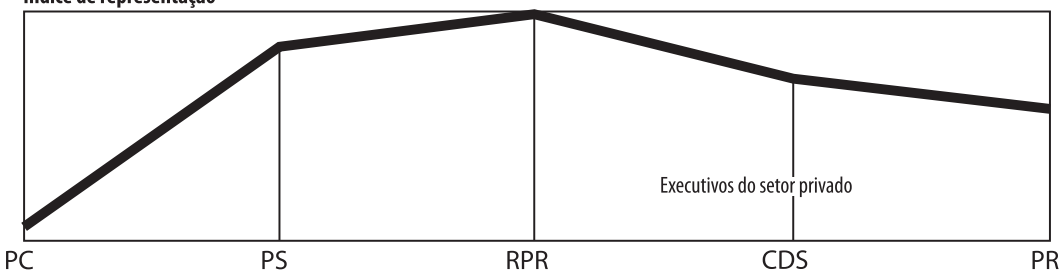

Índice de representação

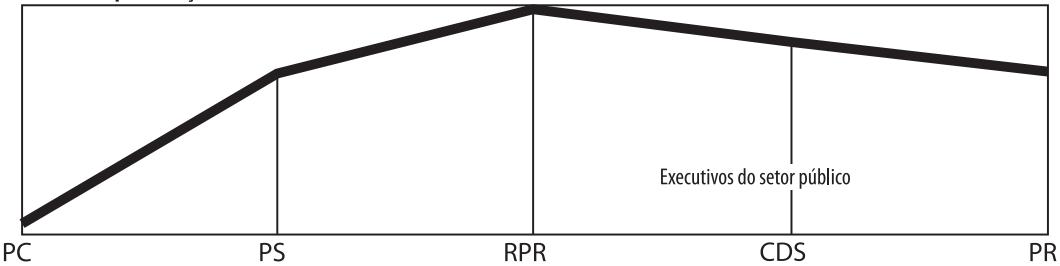

Índice de representação

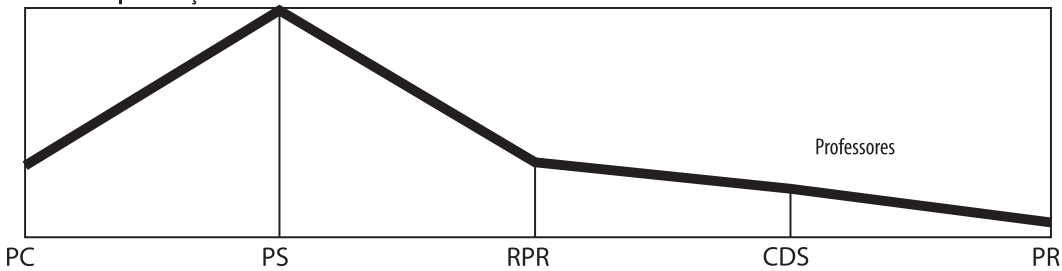

\section{Dominantes e dominados}

Opondo agentes do topo da hierarquia social, a competição política tange principalmente às classes sociais privilegiadas. Contudo, as classes médias e 
populares não se encontram completamente ausentes, já que uma parte significativa das lideranças do PCF e, em menor grau, do PS vem desses meios. Mais precisamente, a porcentagem dos parlamentares que pertencem a essas classes aumenta quando se vai da UDF à RPR, da RPR ao PS e do PS ao $\mathrm{PCF}^{33}$. Na medida em que (re)expressa as clivagens sociais, a competição política exprime, portanto, por mediações a serem ainda desveladas, a oposição entre os agentes que ocupam as posições dominadas e aqueles que ocupam as posições dominantes na estrutura social global. Podem-se encontrar sinais dos conflitos entre os operários e os proprietários dos meios de produção ressaltados pela tradição marxista, ou da luta mais surda que opõe classes médias e superiores nas diferenças entre os partidos de esquerda e os da maioria ou mesmo nos partidos de esquerda entre $\mathrm{si}^{34}$. Porém, mesmo que a luta política seja, nesse sentido, uma luta de classes, os dados relativos à origem dos quadros políticos mostram que ela também é, e principalmente, uma luta entre as frações das classes superiores.

No entanto, essa luta das frações de classes não deixa de ter analogia com a luta social global. Tudo indica, com efeito, que a competição política opõe principalmente os agentes que ocupam posições dominadas das classes superiores aos agentes que ocupam posições dominantes. Este é o sentido, por exemplo, da Tabela 6, que avalia os estudos dos deputados com formação superior. Pode-se constatar que a porcentagem dos deputados que estudaram nas grandes écoles ${ }^{35^{*}}$ aumenta regularmente quando se percorre o leque das posições políticas do PCF ao PR. Do mesmo modo, a porcentagem dos deputados aprovados nos grandes concursos jurídicos e médicos que dão acesso aos lugares mais proveitosos no mercado social aumenta, ao passo que, inversamente, a dos deputados com um diploma de agrégation ou um CAPES em Letras, cuja rentabilidade social é menor, diminui quando se vai em direção à "direita" no interior do campo político. Em um nível mais baixo da hierarquia escolar, a porcentagem dos deputados que fizeram estudos superiores na área de Letras aumenta, enquanto a porcentagem correspondente aos estudos jurídicos e médicos tende a diminuir quando se vai do PR ao PCF.

\footnotetext{
33 Uma outra medida do vínculo entre a posição no campo político e a posição social pode ser fornecida pelo nível escolar. A porcentagem dos deputados eleitos em 1978 que fizeram curso superior passa de $12,8 \%$ no PCF para $57,8 \%$ no PS, $59,4 \%$ no CDS, $71,8 \%$ no PR e $72,1 \%$ no RPR.

34 A distância social que separa a bancada socialista da comunista tem certamente relação com o antagonismo latente que opõe as classes populares e as classes médias.

35 *São instituições de ensino superior mais prestigiosas da França, que preparam os futuros dirigentes do país, tais como a École Nationale de l'Administration (ENA), a École Polytechnique, o Institut d'Études Politiques (IEP, mais conhecido como Sciences Po) (NT).
} 
Tabela 6: Tipo de estudos superiores dos deputados conforme o pertencimento partidário

\begin{tabular}{|c|c|c|c|c|c|c|c|c|c|}
\hline & \multicolumn{2}{|c|}{$P C F$} & \multicolumn{2}{|c|}{ SFIO-PS } & \multicolumn{2}{|c|}{ MRP, CDS } & \multicolumn{2}{|c|}{ UNR, RPR } & \multirow{2}{*}{$\begin{array}{c}\text { Independentes } \\
\text { - PR } \\
1958^{1}\end{array}$} \\
\hline & $1958^{1}$ & $1978^{2}$ & $1958^{1}$ & $1978^{2}$ & $1958^{1}$ & $1978^{2}$ & $1958^{1}$ & $1978^{2}$ & \\
\hline $\begin{array}{l}\text { grandes } \\
\text { écoles }\end{array}$ & & 9,1 & 11,0 & 16,9 & 16,2 & 21,1 & 17,6 & 22,1 & 20,0 \\
\hline $\begin{array}{c}\text { grandes } \\
\text { concursos } \\
\text { de medicina, } \\
\text { direito } 4\end{array}$ & & 0 & - & 3,4 & - & 5,3 & - & 7,1 & - \\
\hline $\begin{array}{l}\text { grandes } \\
\text { concursos } \\
\text { de letras, } \\
\text { ciências } 5 \\
\end{array}$ & & 27,3 & - & 15,3 & - & 0 & - & 5,3 & - \\
\hline $\begin{array}{l}\text { petites } \\
\text { écoles }^{6}\end{array}$ & & 27,3 & - & 0 & - & 0 & - & 7,1 & - \\
\hline Sciences Po & & 0 & & 8,5 & & 21,1 & & 12,4 & \\
\hline $\begin{array}{c}\text { direito, } \\
\text { ciências } \\
\text { econômicas }\end{array}$ & & 0 & 29,6 & 25,4 & 59,5 & 31,6 & 47,3 & 19,5 & 57,6 \\
\hline $\begin{array}{l}\text { medicina, } \\
\text { farmácia }\end{array}$ & & 18,2 & 33,3 & 13,6 & 5,4 & 5,3 & 20,6 & 17,7 & 17,6 \\
\hline Letras & & 18,2 & 22,2 & 8,5 & 18,9 & 0 & 13,7 & 6,2 & 3,5 \\
\hline ciências & & 0 & 3,7 & 6,8 & 0 & 10,5 & 0,8 & 0 & 1,2 \\
\hline $\begin{array}{l}\text { diversos, sem } \\
\text { indicaçãa }\end{array}$ & & 0 & - & 1,7 & - & 5,3 & - & 2,7 & - \\
\hline Total & $N=1$ & $\begin{array}{c}100 \% \\
N=11\end{array}$ & $\begin{array}{c}100 \% \\
N=27\end{array}$ & $\begin{array}{c}100 \% \\
N=59\end{array}$ & $\begin{array}{c}100 \% \\
N=37\end{array}$ & $\begin{array}{c}100 \% \\
N=19\end{array}$ & \begin{tabular}{|c|}
$100 \%$ \\
$N=131$
\end{tabular} & $\begin{array}{c}100 \% \\
N=113\end{array}$ & $\begin{array}{c}100 \% \\
N=85\end{array}$ \\
\hline
\end{tabular}

1. Mattei Dogan, “Changement de regime et changement de personnel”, art.cit., p. 264.

2. De acordo com os arquivos do Congresso analisados por mim.

3. École Polytechnique, École Normale Superieure (ENS), École Nationale Supérieure d'Agronomie, École Nationale de la France d'outre-mer (ENFOM), École de Marine, École Centrale des arts et manufactures, École spéciale militaire de SaintCyr, École des Hautes Études Commerciales de Paris (HEC).

4. Agrégation de Direito ou Medicina, concurso vestibular para os "grandes corpos" antes da criação da ENA.

5. Agrégation, CAPES.

6. Écoles Supérieures de Commerce, École Normale Supérieure d'Éducation Physique (ENSEP), École Nationale Supérieure de l'Aéronautique et de l'Espace, École Supérieure d'Agriculture.

É essa homologia entre as posições ocupadas na estrutura social global e na estrutura das classes superiores (ou das classes médias) que leva, por exemplo, a compreender a lógica do recrutamento do PCF voltada para as classes dominadas (como os operários) e para os agentes que ocupam posições dominadas nas classes superiores (professores) ou nas classes médias (professores primários). 
Obedecendo ao princípio de estruturação da luta social global, a luta entre as frações das classes superiores pode encontrar a mesma expressão política. Compreende-se assim que, pela combinação da oposição entre dominantes e dominados que a estrutura e pelo efeito de seleção social que produz, a competição política exprime principalmente o antagonismo entre o polo intelectual e o polo econômico das classes dominantes. Limitando as possibilidades de ascensão política dos membros das classes populares ou, como se quiser, dos dominados globais, a concorrência política deixa aos intelectuais - dominantes, do ponto de vista da posse do capital cultural; dominados, do ponto de vista da posse do capital econômico presentemente preponderante na atribuição das posições sociais e, portanto, dominados locais ${ }^{36}$ - a maior parte da expressão do protesto social. Compreende-se igualmente que, mesmo quando assume a linguagem da luta das classes, a luta política traduz na prática, na maioria das vezes, o antagonismo que separa os intelectuais e a burguesia econômica. Embora se encontrem na luta política sinais diretos das oposições entre classes devido ao recrutamento do PS e sobretudo do PCF voltado às classes médias e populares, as características dos agentes do campo político indicam que essa luta expressa mais ainda os conflitos inerentes às classes superiores.

A bancada da maioria é formada por partidos cujas lideranças são maciçamente originárias de ou ligadas à fração econômica dominante das classes superiores. Inversamente, o recrutamento dos dirigentes do PS e do PCF, embora seja mais diversificado, privilegia nitidamente o polo intelectual dominado. Observase, de resto, que as alianças políticas obedecem bastante a essa lógica. A liderança do MRP e do Partido Radical Valoisien se aproximou do polo econômico, e esses partidos vieram reforçar o bloco político no poder. O MRG atenuou seus laços com os meios econômicos e os profissionais liberais, reforçando-os com o campo intelectual quando se aliou ao PS e ao PCF. O recrutamento no polo intelectual se intensificou quando o PS sucedeu à SFIO, com uma reestruturação à esquerda.

Essa oposição entre as duas grandes frações se desdobra em oposições secundárias que também expressam as estruturações internas nas classes superiores. Por exemplo, vimos que as lideranças do PR e da RPR estão ligadas ao polo econômico, mas as do PR pertencem mais às frações tradicionais, enquanto as da RPR se originam com mais frequência nas frações novas, principalmente assalariadas. Os quadros do CDS são, nesse aspecto, mais próximos do $\mathrm{PR}$ do que da RPR e, ao entrar na UDF, esse partido apenas se voltou para onde já pendia.

${ }^{36}$ Sobre essas noções, cf. Bourdieu e Saint-Martin (1976). 
Os dirigentes comunistas que pertencem ao campo intelectual ocupam também posições inferiores nesse campo e são de origem social mais baixa do que os socialistas.

As oposições entre os dois principais polos das classes superiores tendem igualmente a se refratar nas demais frações. Os líderes da UDF e da RPR pertencem, na maioria das vezes, à alta função pública, principalmente aos "grandes corpos" do Estado ${ }^{37}$ - em 1978, a porcentagem dos deputados oriundos do setor público e aprovados nos grandes concursos de recrutamento passa de $42 \%$ no PS para $54 \%$ no PR e $57 \%$ no RPR; a porcentagem de exalunos da ENA é respectivamente de $37 \%$ no PS, $30 \%$ na $\mathrm{RPR}^{38}$ e $46 \%$ no PR; os deputados da UDF parecem ser de origem social mais alta e mais ligados à burguesia econômica tradicional do que os da RPR. Em contrapartida, uma grande proporção das lideranças socialistas provém do que se poderia chamar de pequena parafunção pública ou pequena função pública superior (diretores de política habitacional, diretores de hospitais, gestores universitários, chefes de repartição na Previdência Social, funcionários graduados contratados em empresas públicas ou na administração central, diretores municipais, auditores do Tesouro, dos Correios e da rede ferroviária estatal). Eles ocupam as posições baixas - simbólica e hierarquicamente dominadas - da função pública superior (serviços externos dos ministérios, empresas públicas ou coletividades locais em relação à administração central, funcionários contratados em oposição aos titulares, funcionários recrutados por concursos internos em relação aos concursos externos, gestores administrativos em relação aos administradores ministeriais e aos membros dos "grandes corpos"). A origem escolar desses funcionários mostra que frequentemente mantêm com as lideranças da UDF ou da RPR relação semelhante à dos estudantes universitários com os egressos das grandes écoles, principalmente da Sciences Po, ou dos graduados em Direito com os ex-alunos da ENA. Com diploma igual (por exemplo, o diploma do Instituto de Estudos Políticos de Paris - IEP e a graduação em Direito), os deputados PS ocupam no setor público posições claramente menos prestigiosas (diretores de hospitais, encarregados de missão na empresa estatal de eletricidade, economistas em empresas públicas) do que os da UDF ou da RPR (administradores

${ }^{37}$ Os grandes corpos, na França, se referem aos altos funcionários da função pública, cujos membros são geralmente recrutados na ENA ou na École Polytechnique e assumem grandes responsabilidades administrativas nos altos escalões do Estado (NT).

${ }^{38}$ Esse número mais baixo explica-se pelo fato de que os deputados RPR geralmente mais velhos entraram nos grandes corpos antes da criação da ENA. 
municipais, diretores de ministério, ministros plenipotenciários, carreiras administrativas), como se sua origem social mais baixa ${ }^{39}$ limitasse a rentabilidade de seus títulos escolares no mercado da função pública. Quando saem da ENA, com frequência pertencem paradoxalmente aos grandes corpos (em 1978, 5 dos 7 eleitos socialistas ex-alunos da ENA vinham da Auditoria da Fazenda, do Conselho de Estado ou do Tribunal das Contas, ou seja, 71\% contra 38\% na UDF e 55\% na RPR), mas não parecem seguir a carreira autorizada por sua formação ${ }^{40}$, provavelmente, mais uma vez, devido à origem social.

Os professores apresentam, do mesmo modo, um conjunto sistemático de diferenças conforme pertençam ao PCF e ao PS, ou à UDF e à RPR. De fato, tudo indica que os professores dos grupos socialistas ou comunistas ocupam posições baixas nas hierarquias ou sub-hierarquias acadêmicas, ao contrário de seus homólogos da maioria que apresentam mais seguidamente os sinais do sucesso acadêmico. Têm como menos frequência um diploma de agrégation ou das grandes écoles - 33\% no PS e 57\% no RPR - ou, quando universitários, o grau de professor titular (nenhum universitário comunista eleito em 1978 é professor titular, contra $25 \%$ no PS, $60 \%$ na UDF e $88 \%$ na RPR). Os professores dos partidos da maioria se revelam igualmente mais próximos do polo econômico: dão aulas no ensino privado (nenhum professor das bancadas socialistas ou comunistas leciona nesse setor, contra 7\% na RPR e 30\% na UDF), ou sua especialidade médica, jurídica ou econômica pode ser mais facilmente rentabilizada no mercado dos bens e dos serviços (a porcentagem dos professores de Medicina, Direito ou Ciências Econômicas passa de 0\% no PCF para $11 \%$ no PS, $30 \%$ na UDF e $36 \%$ na RPR). Ao contrário, os professores socialistas ou, mais ainda, comunistas são em geral especializados nas disciplinas ligadas às Letras e se encontram mais ligados ao polo intelectual. Os deputados socialistas e comunistas ${ }^{41}$ situam-se, portanto, negativamente

39 O pai de $9 \%$ dos deputados socialistas eleitos em 1968 e pertencentes às classes superiores pertencia a essas mesmas classes contra 67\% na UDR e $84 \%$ nos RI. Se remontarmos à terceira geração, os dados são 18\%, 46\% e 63\% respectivamente. Cf. Cayrol, Parodi e Ysmal (1976, p. 52-53).

${ }^{40} \mathrm{Na}$ medida em que sua carreira, muito curta, permite medi-lo, parece, por exemplo, que os eleitos OS originários da ENA tenham permanecido frequentemente em seu corpo de origem e tenham investido muito cedo numa área fora da função pública. Assim, eles parecem mais ligados ao campo intelectual (participação em revistas) do que seus homólogos da maioria.

${ }^{41}$ Ainda que mais titulados em média do que seus homólogos socialistas, os deputados comunistas ensinam em geral no secundário, o que parece denotar uma maior dificuldade - provavelmente ligada à sua origem - para valorizar seus títulos no mercado da concorrência acadêmica. Também sua formação é, com mais frequência, literária. 
em relação aos diversos critérios que definem a posição no campo acadêmico. Geralmente, ensinam no secundário e têm com menos frequência o diploma de agrégation; quando universitários, são quase sempre professores assistentes das disciplinas da área de Letras. Já os deputados da maioria acumulam todos os atributos que definem as posições docentes com rentabilidade social (mas não intelectual) máxima. Por exemplo, eles têm fortes chances de serem professores titulares das faculdades de Medicina ou Direito e, mesmo quando ocupam posições mais baixas, apresentam certas características que os tornam dominantes locais. Se há pouca probabilidade de serem professores da área de Letras sem o título de agrégé do ensino secundário, é bem possível, quando isso ocorre, que deem aulas no ensino privado e (ou) que sejam diretores, vice-diretores ou administradores escolares.

Embora as informações sejam mais raras e difíceis de coletar, tudo indica que a lógica é a mesma entre profissionais liberais ou entre altos executivos do setor privado. Tudo parece opor, por exemplo, os médicos socialistas (frequentemente "rurais", generalistas, associados à previdência social agrícola ou à Seguridade Social) e os deputados da maioria (em geral, titulares da agrégation, especialistas, moradores dos bairros nobres das grandes cidades); um advogado socialista especializado em questões trabalhistas, com clientela incerta e desfavorecida, e seu adversário do Partido Republicano, advogado comercial credenciado no Tribunal do Comércio, membro do movimento de jovens empresários e presidente-fundador do Lions Club. A distância social também parece grande entre os altos executivos do setor privado que pertencem às bancadas parlamentares da maioria e seus homólogos socialistas. Os do setor privado quase sempre têm curso superior (a porcentagem dos altos executivos do privado que não fizeram estudos universitários passa de $60 \%$ no PS para $53 \%$ na RPR e para 40\% na UDF), ou estudaram nas grandes écoles ou escolas comerciais (sua porcentagem passa de $20 \%$ no PS para $47 \%$ na UDF, mas para apenas $7 \%$ na RPR); geralmente são também presidentes e diretores de empresas importantes, de bancos ou de sindicatos patronais. Entre os socialistas, encontram-se tanto diretores de cooperativas quanto executivos com perfil mais clássico.

Quando pertencem a uma mesma categoria social, os deputados socialistas ou comunistas não ocupam, portanto, a mesma posição social que os deputados da maioria. Os socialistas e comunistas ocupam as posições baixas no campo das relações de concorrência que define a categoria, ao passo que os deputados da maioria detêm as posições dominantes. 
Esse princípio de estruturação da competição política e, por conseguinte, do sucesso político, também se encontra nas classes médias. O PCF e o PS recrutam suas lideranças nas frações mais baixas (empregados de escritório, técnicos), ao contrário dos partidos da maioria, mais ligados ao polo econômico dessas classes (pequenos comerciantes, fração superior dos executivos assalariados do setor privado, tais como os representantes comerciais); a RPR "volta-se” mais, conforme o princípio de homologia, na direção dos executivos assalariados.

\section{Esquema resumido dos princípios de estruturação do recrutamento político}

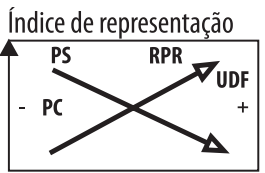

Professores

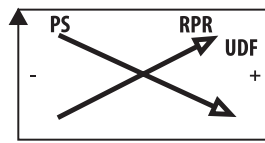

Gerentes, públicos

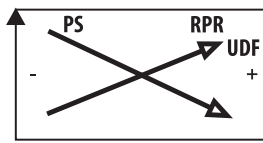

Gerentes, privados

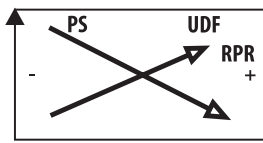

Profissões liberais

Índice de representação

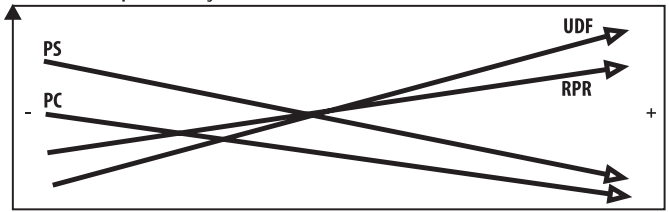

Classes superiores

Índice de representação

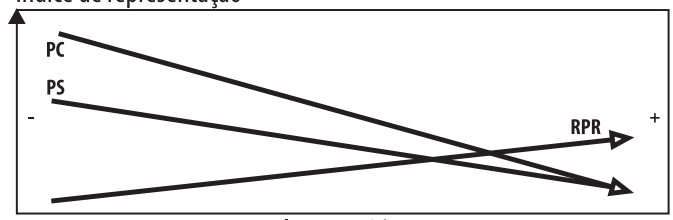

Classes médias

Índice de representação

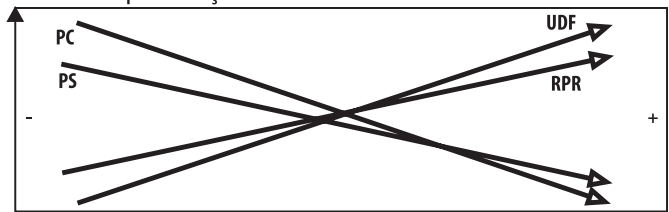

Estrutura social global

0 sinal + simboliza as posições (local ou globalmente) dominantes; 0 sinal -, as posições (local ou globalmente) dominadas.

\section{Os mecanismos da influência e da representação política: algumas hipóteses}

Essa lógica do recrutamento dos quadros políticos nos níveis das classes médias permite levantar algumas hipóteses referentes à influência política 
exercida pelos partidos. De fato, tudo leva a pensar que o grau de apoio político das diversas camadas sociais e, de modo mais geral, que os mecanismos de representação também obedecem aos princípios que determinam o recrutamento dos quadros. Tomando o comportamento eleitoral como um indicador aproximado ${ }^{42}$ dessa influência, constata-se que há bastante similitude entre o recrutamento social dos partidos e suas zonas de força no espaço social. O PCF consegue seus melhores resultados eleitorais entre os professores primários, operários, empregados administrativos e técnicos, que lhe fornecem igualmente a maior parte de suas lideranças, mas também, deve-se ressaltar, entre os empregados de serviços ou os serviços médicos e sociais, quase ausentes de seus órgãos diretivos ${ }^{43}$. São os professores primários e os professores titulares que demonstram as mais fortes disposições a votar pela "esquerda não comunista" e que dirigem essas organizações, mas também os artistas, empregados administrativos e contramestres. Do mesmo modo, o "gaullismo" consegue seus melhores resultados eleitorais entre os policiais e os militares, profissionais liberais, industriais e altos executivos - categorias que fornecem a maioria de seus dirigentes ${ }^{44}$ - e, menos nitidamente, entre os pequenos comerciantes e executivos, ausentes em geral de suas instâncias de direção.

O recrutamento social dos partidos é acompanhado, portanto, de uma influência eleitoral diferencial muito comparável, confirmando que as oposições políticas constituem uma expressão simbólica das oposições sociais. Especialmente nas intenções de voto, encontram-se as mesmas oposições internas às classes superiores que transpareciam nas características sociais das lideranças partidárias. As intenções de voto em favor do PCF ou da esquerda não comunista aumentam regularmente quando se vai do polo econômico das classes superiores, onde essas formações obtêm resultados nitidamente mais fracos do que na média do eleitorado, ao polo intelectual, onde sua influência eleitoral é, ao contrário, proporcionalmente maior. De modo inverso, os partidos gaullistas ou centristas, bem menos influentes eleitoralmente nos meios intelectuais do que no eleitorado, veem as intenções de voto aumentarem em seu favor com a proximidade do polo

\footnotetext{
${ }^{42}$ Aproximado, pois obedecendo a outros fatores, como o nível de politização e de competência política, que vêm perturbar as relações entre as camadas sociais e os partidos políticos.

${ }^{43}$ Eu me baseio nos dados muitíssimo precisos de Michelat e Simon (1975, p. 296-297). Essas relações valem sobretudo para os chefes da casa.

44 À exceção da categoria "exército e polícia".
} 
econômico, onde seu peso eleitoral é sensivelmente mais elevado do que na média da população (Tabela 7).

Mas essa correspondência entre as características sociais das lideranças e dos eleitores dos partidos encontra limites no fato de que todos os partidos conseguem bons resultados eleitorais em certas categoriais sociais ausentes de seus órgãos diretivos. No entanto, parece que essa correspondência também exerce um efeito indireto, pois é surpreendente que haja uma relação de homologia entre essas categorias e as frações de proveniência das lideranças.

A homologia de funcionamento entre as classes médias e superiores, que se manifesta no fato de que, quando recrutam nas classes médias, partidos como a RPR ou o PR selecionam agentes que nelas ocupam posições homólogas àquelas de suas lideranças nas classes superiores, parece permitir aos diversos partidos influenciar certos grupos sociais ainda que nenhum de seus líderes ou poucos deles venham desses grupos. O PR ou a RPR recrutam apenas uma porcentagem bem baixa de seus deputados no polo econômico das classes médias, mas a homologia de posição entre esse polo e o polo econômico das classes superiores de onde vem a maioria de seus dirigentes lhes permitiria exercer uma forte influência sobre ele.

Com efeito, constata-se que, tanto para as classes médias como para as classes superiores, a porcentagem das intenções de voto para os partidos gaullistas e centristas aumenta (enquanto as porcentagens correspondentes para o PCF ou para a esquerda não comunista diminuem) com a proximidade do polo econômico, e que essa porcentagem é máxima nos partidos gaullistas com os executivos (Tabela 7). Esse mecanismo também parece funcionar para o PS, cuja audiência em certas camadas das classes superiores (artistas), das classes médias (empregados administrativos, executivos), ou das classes populares (contramestres) deve certamente mais a essa representação por homologia do que à representação direta assegurada por agentes que pertencem ao grupo social representado (cf. esquema p. 187). Provavelmente, o mesmo mecanismo atue no PCF, cujos resultados junto aos trabalhadores manuais, operários especializados ou empregados de serviços (mas não junto aos empregados agrícolas) se explicam, sem dúvida, pelo fato de que tais categoriais, que se encontram na parte inferior de todas as hierarquias, se afinam com os quadros do PCF, que também ocupa as posições baixas nos diversos campos de atuação (cf. esquema p. 190). 
Tabela 7: Comportamento eleitoral e posição social ${ }^{1}$

\begin{tabular}{|c|c|c|c|c|c|c|c|c|}
\hline \multicolumn{9}{|c|}{ classes superiores } \\
\hline & $\begin{array}{l}\text { artis- } \\
\text { tas }\end{array}$ & $\begin{array}{l}\text { professor } \\
\text { universi- } \\
\text { tário }\end{array}$ & $\begin{array}{l}\text { enge- } \\
\text { nheiro }\end{array}$ & $\begin{array}{l}\text { altos exe- } \\
\text { cutivos }\end{array}$ & $\begin{array}{l}\text { grandes } \\
\text { comer- } \\
\text { ciantes }\end{array}$ & $\begin{array}{l}\text { profissões } \\
\text { liberais }\end{array}$ & $\begin{array}{c}\text { indus- } \\
\text { triais }\end{array}$ & $\begin{array}{c}\text { conjunto } \\
\text { das intenções } \\
\text { de voto }\end{array}$ \\
\hline PCF & & & 8 & 2 & 0 & 6 & & 13 \\
\hline $\begin{array}{l}\text { esquerda não- } \\
\text {-comunista }\end{array}$ & 33 & 35 & 25 & 22 & 20 & 11 & 6 & 23 \\
\hline centro & 4 & 9 & 16 & 16 & 20 & 19 & 29 & 13 \\
\hline gaullismo & 19 & 18 & 36 & 42 & 32 & 45 & 42 & 30 \\
\hline sem resposta & 30 & 22 & 16 & 18 & 20 & 17 & 23 & 21 \\
\hline total & $100 \%$ & $100 \%$ & $100 \%$ & $100 \%$ & $100 \%$ & $100 \%$ & $100 \%$ & $100 \%$ \\
\hline \multicolumn{9}{|c|}{ classes médias } \\
\hline & $\begin{array}{c}\text { profes- } \\
\text { sores } \\
\text { primários }\end{array}$ & $\begin{array}{l}\text { empregados } \\
\text { de escritório }\end{array}$ & \begin{tabular}{l|c} 
os & técni- \\
io & cos
\end{tabular} & $\begin{array}{l}\text { empre- } \\
\text { gados do } \\
\text { comércio }\end{array}$ & gerentes & $\begin{array}{l}\text { arte- } \\
\text { sãos }\end{array}$ & $\begin{array}{l}\text { pequenos } \\
\text { comercian- } \\
\text { tes }\end{array}$ & $\begin{array}{c}\text { conjunto das } \\
\text { intenções de } \\
\text { voto }\end{array}$ \\
\hline PCF & 25 & 17 & 16 & 9 & 9 & 10 & 5 & 13 \\
\hline $\begin{array}{c}\text { esquerda não- } \\
\text {-comunista }\end{array}$ & 38 & 30 & 25 & 22 & 24 & 21 & 18 & 23 \\
\hline centro & 4 & 12 & 11 & 16 & 12 & 11 & 19 & 13 \\
\hline gaullismo & 16 & 26 & 32 & 31 & 35 & 34 & 33 & 20 \\
\hline sem resposta & 16 & 15 & 15 & 23 & 18 & 25 & 23 & 21 \\
\hline total & $100 \%$ & $100 \%$ & $100 \%$ & $100 \%$ & $100 \%$ & $100 \%$ & $100 \%$ & $100 \%$ \\
\hline
\end{tabular}

classes populares

\begin{tabular}{c|c|c|c|c}
\hline & contramestres & $\begin{array}{c}\text { conjunto dos } \\
\text { operários }\end{array}$ & $\begin{array}{c}\text { trabalhadores } \\
\text { não qualificados }\end{array}$ & $\begin{array}{c}\text { conjunto das } \\
\text { intenções de voto }\end{array}$ \\
\hline PCF & 10 & 22 & 27 & 13 \\
\hline $\begin{array}{c}\text { esquerda não- } \\
\text {-comunista }\end{array}$ & 30 & 25 & 21 & 23 \\
\hline centro & 10 & 9 & 7 & 13 \\
\hline gaullismo & 31 & 25 & 26 & 30 \\
\hline sem resposta & 18 & 18 & 19 & 21 \\
\hline total & $100 \%$ & $100 \%$ & $100 \%$ & $100 \%$ \\
\hline
\end{tabular}

1. Guy Michelat, Michel Simon, art. cit. p. 296-297. Esta tabela retoma apenas as categorias cujo comportamento eleitoral parece corresponder à lógica analisada neste artigo, excluindo aquelas que parecem submetidas a outros determinismos (trabalhadores agrícolas, clero, polícia, relação entre os operários especializados e os operários qualificados), ou que são heterogêneas demais (serviços médicos e sociais, agricultores, empregados de serviços). Essas porcentagens só valem para os chefes de família. 
As condições sociais do sucesso político levam então as lutas internas às classes médias e populares, assim como as lutas entre classes, a se expressarem amplamente por mandato. Enquanto os conflitos entre as frações das classes superiores são expressos politicamente por agentes que pertencem a essas frações, as oposições internas às demais classes, entre as outras classes ou entre as outras classes e as classes superiores são expressas com frequência por agentes externos. Embora as lutas políticas manifestem diretamente, em certos casos, os interesses de certas frações das classes médias ou populares, já que o PCF ou mesmo o PS recrutam seus quadros dirigentes ou uma parte de deles nessas frações, elas traduzem em geral os conflitos internos às classes superiores, cujos ecos repercutem e encontram sentido nos outros grupos sociais devido à homologia das relações que estruturam o espaço social em seus diversos níveis. Em outras palavras, é porque o polo intelectual ocupa uma posição dominada no interior das classes superiores que as tomadas de posição de seus porta-vozes políticos podem encontrar alguma ressonância nas frações dominadas das classes médias ou nos grupos que ocupam as posições globalmente dominadas da estrutura social. É porque expressam o ponto de vista da fração dominante das classes superiores que partidos que recrutam seus quadros nesse setor do espaço social podem reforçar sua base social ou eleitoral graças aos agentes que ocupam uma posição dominante similar nas classes médias ou populares.

Nesse sentido, a maioria das oposições políticas atuais traduz principalmente a luta das frações das classes dominantes e quase sempre só expressa as lutas de classes de forma indireta.

\section{Anexo: Partidos políticos franceses}

CD - Centre Démocrate (Centro Democrata), movimento político francês fundado em 1965 e que reúne membros do MRP, independentes e radicais. Transforma-se no CDS em 1976 e em Force Démocrate em 1995.

CDS - Centre des Démocrates Sociaux (Centro dos Democratas Sociais), partido de centro-direita, criado em 1976 e dissolvido em 1995; é um dos membros fundadores da UDF.

CNIP ou CNI - Centre National des Indépendants et Paysans (Centro Nacional dos Independentes e Camponeses), partido liberal-conservador, criado em 1949. 
MRG - Mouvement de Radicaux de Gauche (Movimento dos Radicais de Esquerda), criado em 1973.

MRP - Mouvement Républicain Populaire (Movimento Republicano Popular), partido democrata-cristão, fundado em 1944 e dissolvido em 1967.

Parti Radical Valoisien (Partido Radical Valoisien), partido francês mais antigo, de centro-direita, criado em 1901. Em 2011, toma parte da criação da ARES, Aliança Republicana, Ecologista e Social.

PC - Parti Communiste Français (Partido Comunista Francês), fundado em 1920 com o nome de Seção francesa da Internacional Comunista.

PDM - Progrès et Démocratie Moderne (Progresso e Democracia Moderna), grupo centrista do Congresso, constituído em 1967 e 1968, composto por membros de partidos políticos de direita não gaullista e do centro.

PR - Parti Républicain (Partido Republicano), criado em 1977 e dissolvido em 1997, foi substituído pela Démocratie libérale (DL).

PS - Parti Socialiste (Partido Socialista), herdeiro da Seção Francesa da Internacional Operária (SFIO), fundado em 1905, o PS foi criado em 1969.

RI - Parti des Républicains Indépendants (Partido dos Republicanos Independentes), criado em 1949 e dissolvido em 1962.

RPF - Rassemblement du Peuple Français (Coalizão do Povo Francês), movimento político fundado por de Gaulle (1947-1955); foi o único a congregar todos os gaullistas.

RPR - Rassemblement pour la République (Coalizão pela República), partido de direita vinculado ao gaullismo, foi criado em 1976 e autodissolvido em 2002 na Union pour un mouvement populaire (UMP).

RS - Républicains Sociaux (Republicanos Sociais) ou CNRS Centre National des Républicains Sociaux (Centro Nacional dos Republicanos Sociais), partido de apoio ao General de Gaulle entre 1956 e 1958.

SFIO - Section française de l'Internationale Ouvrière (Seção Francesa da Internacional Operária), partido socialista criado em 1905 e dissolvido em 1969. Naquele ano, tornou-se o Partido Socialista.

UDF - Union pour la Démocratie Française (União pela Democracia Francesa), partido de centro ou centro-direita, fundado em 1978 para apoiar o presidente Valéry Giscard d'Estaing, é hoje membro fundador do Mouvement Démocrate (MoDem). 
UDR - Union des Démocrates pour la République (União dos Democratas pela República), nome adotado de 1971 a 1976 pelo partido gaullista; tornou-se em 1976 a RPR.

UNR - Union pour la Nouvelle République (União pela Nova República), fundado em 1958 e destinado a apoiar a ação do General de Gaulle, que reassumiu o poder em junho daquele ano.

\section{Referências bibliográficas}

BOURDIEU, Pierre \& SAINT-MARTIN, Monique. 1976. "Anatomie du goût". Actes de la Recherche en Sciences Sociales, n. 5, p. 4-81.

CAYROL, Roland; PARODI, Jean-Luc \& YSMAL, Colette. 1973. Le député français. Paris: Presses de la Fondation Nationale des Sciences Politiques. DOGAN, Mattei. 1960. "Changement de régime et changement de personnel". Le référendum de septembre et les élections de novembre 1958. Paris: Presses de la Fondation Nationale des Sciences Politiques. . 1961. "Political ascent in a class society". In: MARVICK, Dwaine (ed.). Political decision makers. Chicago: The Free Press.

. 1965. "Note sur le nouveau personnel parlementaire". In: GOGUEL, François (ed.). Le référendum d’octobre et les élections de novembre 1962. Paris: Presses de la Fondation Nationale des Sciences Politiques.

GAXIE, Daniel. 1983. "Les facteurs sociaux de la carrière gouvernementale sous la Cinquième République de 1959 à 1981”. Revue Française de Sociologie, n. XXIV, p. 441-465.

MICHELAT, Guy \& SIMON, Michel. 1975. "Catégories sócio-professionnelles em milieu ouvrier et comportements politiques”. Revue française de science politique, v. 25, n. 2, p. 296-297.

\section{Resumo}

A análise da posição social e da origem das lideranças partidárias revela que os mecanismos atuais de recrutamento político tendem a favorecer as classes superiores da sociedade, embora cada partido privilegie a ascensão de frações distintas dessas classes. As oposições entre partidos que estruturam o funcionamento do campo político mostram-se, assim, como a duplicação (por outro lado, relativamente autônoma) da estruturação interna das classes superiores. As diferenças que separam, por um lado, os dirigentes do Partido Comunista Francês (PCF) e do Partido Socialista Francês (PS) e, por outro, os da Coalizão pela República (RPR) e da União pela Democracia Francesa (UDF) são, por exemplo, forte- 
mente marcadas pela oposição entre os polos intelectual e econômico dessas classes. Do mesmo modo, quando buscam em outros espaços, o PCF e PS recrutam sobretudo agentes que ocupam as posições inferiores-dominadas, ao passo que a UDF e a RPR privilegiam o recrutamento de agentes que se encontram nas posições superiores-dominantes. Esse jogo de homologias permite também compreender a lógica do recrutamento das classes médias e popular e formular algumas hipóteses sobre os mecanismos da influência e da representação políticas.

Palavras chave: recrutamento político; classes sociais; partidos.

\section{Abstract}

Analysis of the original social positions of party leaders shows that the present mechanisms of political recruitment tend to favour the upper classes of society, but that each party encourages the ascent of different fractions of these classes. The contrasts between parties which structure the functioning of the political spectrum thus appear to duplicate (quite independently moreover) the internal structures of the upper classes. The differences between the leaders of the PCF and PS on one hand, and the RPR and UDF on the other, bear a strong resemblance, for example, to the contrast between the intellectual and economic poles of these classes. Similarly, when these parties recruit in other strata, the PCF and PS tend to recruit officials in lower-dominated positions, whereas the UDF and RPR prefer to recruit officials in senior-dominant positions. This pattern of homologies also explains the logic behind recruitment aimed at the middle and popular classes, and allows a few assumptions to be made concerning the mechanism of political influence and representation.

Key words: political recruitment; social classes; political parties. 